\title{
Kubrick Sinemasında Tekinsiz Bir Muğlak Mekân: Overlook Oteli ${ }^{1}$
}

\author{
Büşra ÜNVER ${ }^{2 *}$
}

Öz

Çalışmada mimarlık ve sinema arasındaki ilişki mekânsal duyumsamalar bağlamında ele alınmıştır. Çalışmanın amacı mimarlığın ve mekân kavramının disiplinlerarası yaklaşımla irdelenmesi, mimarlık kuramı için yeni açılımlar oluşturulmasıdır. Bu çalışmada incelenen film mekânlarının salt teknik ve matematiksel bir yaklaşımla değil, fenomenolojik -hermeneutik bir yaklaşımla ele alınması yöntem olarak benimsenmiştir. $\mathrm{Bu}$ bağlamda filmdeki mekânların izleyici üzerinde oluşturduğu duyumsamalar çalışmanın odağını oluşturmaktadır. Çalışmada Stanley Kubrick sinemasından 'The Shining' filmi, mekânsal duyumsama bağlamında ele alınmaktadır. Filmin ana mekânları belirlenmiş ve bu mekânlar ile duyumsamalar eşleştirilmiştir. Bu eşleşmeler; lobi - sıkışmışlık, koridorlar - tedirginlik, Torrence Ailesi'nin odası - güvensizlik, asansör - muğlaklık, labirent - kaybolmuşluk, merdiven - panik, balo salonu - yanılsama, banyo saldırganlık olarak ortaya çıkmıştır. Sonuç bölümünde mekânsal duyumsamanın mimarlıkta hem kuram hem de uygulama için önemli bir unsur olduğu, mekânın ve mimarlığın insandan bağımsız düşünülemeyeceği, zaman ve mekân kavramları ile var olan sinema aracılığıyla vurgulanmıştır. Bu çalışmada sinemanın, mimarlık kuramının geliştirilmesine katkı sağlayacağı ve bu alanda yapılacak bilimsel çalışmaların alana yeni bakış açıları getireceği düşünülmektedir.

Anahtar Kelimeler: Sinema, Mekân, Kubrick, The Shining, Tekinsiz

\section{An Uncanny Ambiguous Space in Kubrick's Cinema: Overlook Hotel}

\begin{abstract}
In the study, the relationship between architecture and cinema is discussed in the context of spatial sensations. The aim of the study is to examine the concept of architecture and space with an interdisciplinary approach and to create new expansions for architectural theory. In this study, it is adopted as a method to deal with the film spaces examined with a phenomenological-hermeneutic approach, not with a purely technical and mathematical approach. In this context, the sensations created by the spaces in the film on the audience constitute the focus of the study. In the study, 'The Shining' film from Stanley Kubrick cinema is discussed in the context of spatial sensation. The main spaces of the film were determined and sensations were matched with these spaces. These matches are; lobby - being stuck, corridors - uneasiness, Torrence Family's room - distrust, elevator - ambiguity, labyrinth - disappearance, staircase - panic, ballroom - illusion, bathroom - aggression. In the conclusion part, it is emphasized that the spatial sensation is an important element for both theory and practice in architecture, and that space and architecture cannot be considered independent from human, through cinema that exists with the concepts of time and space. In this study, it is thought that cinema will contribute to the development of
\end{abstract}

\footnotetext{
${ }^{1}$ Yazarın 2012 yılında Bahçeşehir Üniversitesi, Fen Bilimleri Enstitüsü, İç Mekân Tasarımı Programı'nda tamamladığı tezinden üretilmiştir.

${ }^{2}$ Haliç Üniversitesi, Mimarlık Fakültesi, İç Mimarlık Bölümü

* ilgili yazar/Corresponding author: busraunver@halic.edu.tr

Gönderim Tarihi: 24.04.2020

Kabul Tarihi: 11.12.2020
} 
architectural theory and scientific studies in this field will bring new perspectives to the field.

Keywords: Cinema, Space, Kubrick, The Shining, Uncanny

"You're it, not my daddy, you're the hotel." ("Sen O'sun, babam değilsin, sen otelsin.")

-Danny Torrence, The Shining, 1980

\section{GíRiş}

Mimarlık ve sinemanın varoluşunun iki temel unsuru olan 'zaman ve mekân' kavramlarının ortak oluşu düşünüldüğünde bu iki disiplin arasındaki ilişkinin etkileşimden bir adım ötede dahi olduğu söylenebilir. Mimarlık ve sinemanın zamansal ve mekânsal yapılarından dolayı yakın olmaları özünde ikisinin de yaşam ve yaşanan mekânı ifade etmelerinden kaynaklanmaktadır. Pallasmaa'nın da (2007) belirttiği gibi bu iki disiplin ayrıntılı yaşam görüntüleri ortaya çıkarır ve ikisi de yaşamın deneysel sahnelerini yaratırlar.

$\mathrm{Bu}$ çalışmada, mekânın salt fiziksel matematiksel temellere dayanan sınırlı bir anlayıştan öte, birçok disiplinin bir araya geldiği girift bir yapıdan oluştuğu ve insanın mekândan ayrı değil, mekânın her zaman insanla birlikte var olduğunu sinema aracılığıyla gösterilmektedir. Sinemanın kendini yaratırken mimarlığı, mimarlığın ise kendini ararken sinemayı kullanmasından hareketle bu çalışmada, Stanley Kubrick (1980) sinemasından 'The Shining' filmi mekânsal duyumsamalar çerçevesinde incelenmektedir. Bu filmin seçiminde kullanılan mekânların pasif bir dekor veya arka plan olarak kalmaması, mimarinin film anlatısının kendisini oluşturması etkili olmuştur. Disiplinlerarası bakış açısıyla sinema üzerinden mekânsal okumaların ele alındığı bu çalışmanın amacı gereği filmdeki mekânların analizinde fenomenolojik - hermeneutik yaklaşım benimsenmiştir.

\section{THE SHINING VE TEKINSIZLIK}

The Shining'in yarattığı etkiyi tek kelime ile ifade etmek gerekirse şüphesiz en uygun kavram 'tekinsizlik'tir. Bu kavram, tekinsiz/unheimlich/uncanny, Sigmund Freud'un felsefesinin ana taşlarından biridir. Freud tarafından 1919 yılında tanımlanan bir kavram olan 'unheimlich'in temelinde 'aşina olunan bir şeyin içinde yatan rahatsız edicilik' tanımı yatar. Kullanımı 11. yüzyılına dayanan 'heimlich' kelimesinin Alman dilinin etimolojik sözlüğünde (Kluge, 1989), eve/yuvaya ait olan, eve kapanan/çekilen, kendini başkalarından ve yabancılardan gizlediği anlamını taşıdığı, ancak günümüz Almancasında, ev/yuva kelimeleri ile olan bağlantısının artık hissedilmediği açıklaması yer almaktadır. Bir sıfat olarak olumsuzluk ön eki (un-) ile kullanılan 'unheimlich' kelimesi günümüz Almancasında muğlak bir korku hissini ifade etmektedir. Filmin geneli için kullanılan bu kelimenin kökeni eve/yuvaya ait olan mekânı, Freud'un bakış açısıyla korkunun kaynağı yani bastırılanın geri dönüşünü ifade etmektedir. Freud, düş yorumlarında 'unheimlich' kelimesini kavramlaştırarak beden ve ev tasarımları arasında kurduğu benzerliği açıklamak için kullanmaktadır.

The Shining, Freud'un 'unheimlich' kavramının beden ve mekân olarak birebir örtüştüğü, tekinsizlik hissini yaratmak için karakter ve mekânın paralel olarak aynı olguların işlendiği filmdir. Bu yüzden The Shining'in mekânları için yapılacak betimlemelerde sıkça kullanılacak olan tekinsizlik kavramının Overlook Oteli üzerinden okunması Freud'un çalışmalarındaki gibi beden - mekân bağlamında ele alınmıştır. 
Mekân bağlamında incelendiğinde filmin bir otelde geçmesi, kavramın özünde yer alan 'ev' ile birebir örtüşür. Mekân tanıdıktır, o kadar ki kendi evimiz kadar tanıdıktır. İnsanların ilk gereksinimlerinden barınma için inşa edilen yapılardan biri olan otel, filmde insan için en tekinsiz mekân olarak kullanır. Bu, aynı şekilde gerilim filmlerinde sık kullanılan 'ev' için de geçerlidir. Çünkü insan için en tekinsiz olan, en tanıdık olandır. Mekân bağlamında bakılacak olursa da bu 'ev'dir. Filmdeki gibi otelde sadece üç kişi oldukları bilinen fakat her koridor dönüşünde tedirginlik ve gerilim yaratan işte bu 'tekinsizlik' olgusudur.

Tekinsizlik kavramı filmde mekânla olduğu kadar Jack karakteri ile de öne çıkmaktadır. Mekânda bahsedildiği gibi en tanıdık ve güvenilir mekân olan ev tekinsizken, insan bağlamında incelendiğinde Jack karakteri, baba olması ile en tanıdık ve güvenilen karakter olarak 'tekinsiz'i simgelemektedir. Toplumu oluşturan aile kavramı içerisinde çocukların ve eşin sorgusuz güvendiği insan baba iken, filmde bu güven, tekinsiz insanı yaratmak için en iyi temeli oluşturmuştur. Her hareketi sorumluluk sahibi, tanıdık ve güvenilir olan baba, yaşadığı psikolojik durumla beraber önce yavaşça yabancılaşmaya, garip denilebilecek davranışlarda bulunmaya, tekinsizleşmeye ve nihayet cinnete kadar gitmiştir. Bir baba ve ev, yabancılaşıldığında en çok korkutacak iki unsur olarak kullanılmıştır. Bu bağlamda filmde de çoğu kez vurgulanan Jack Overlook Oteli ikilisi artık iki farklı olgu değil, birbirine dönüşen iki olgu olarak kullanılmıştır. Filmde Danny'nin babasına söylediği bir cümle ise bunu özetler niteliktedir: "You're it, not my daddy, you're the hotel." ("Sen O'sun, babam değilsin, sen otelsin.")

\section{OVERLOOK OTELİ VE MEKÂNSAL DUYUMSAMALAR}

The Shining filminde Kubrick, devasa bir mekânda üzerinde hissettiği sorumluluklarla küçülen bir adamın yaşadığı psikolojik durumu ve cinnetini anlatır. Burada mekân, karakterlerin içinde bulundukları psikolojik durumu, koridorları, devasa boyutu, labirenti, steril ve simetrik hacimleri ile çok daha belirgin hale getiren bir olgudur. Filmdeki insan - mekân ölçeği göz önüne alınacak olunursa, film, çok daha dengeli ve makul oranlarda bir mekânda işlenseydi, Jack'in içinde bulunduğu gerilimli ve tekinsiz durumunu izleyiciye yansıtmanın o denli etkisiz olacağı açıktır. Fakat Overlook Oteli (Şekil 1), insanı küçülten yüksek ve köşeyi her döndüğünde karşısına set çeken duvarları, dışındaki labirenti ile psikolojik gerilim için yadsınamaz bir etki ile filmde var olur.

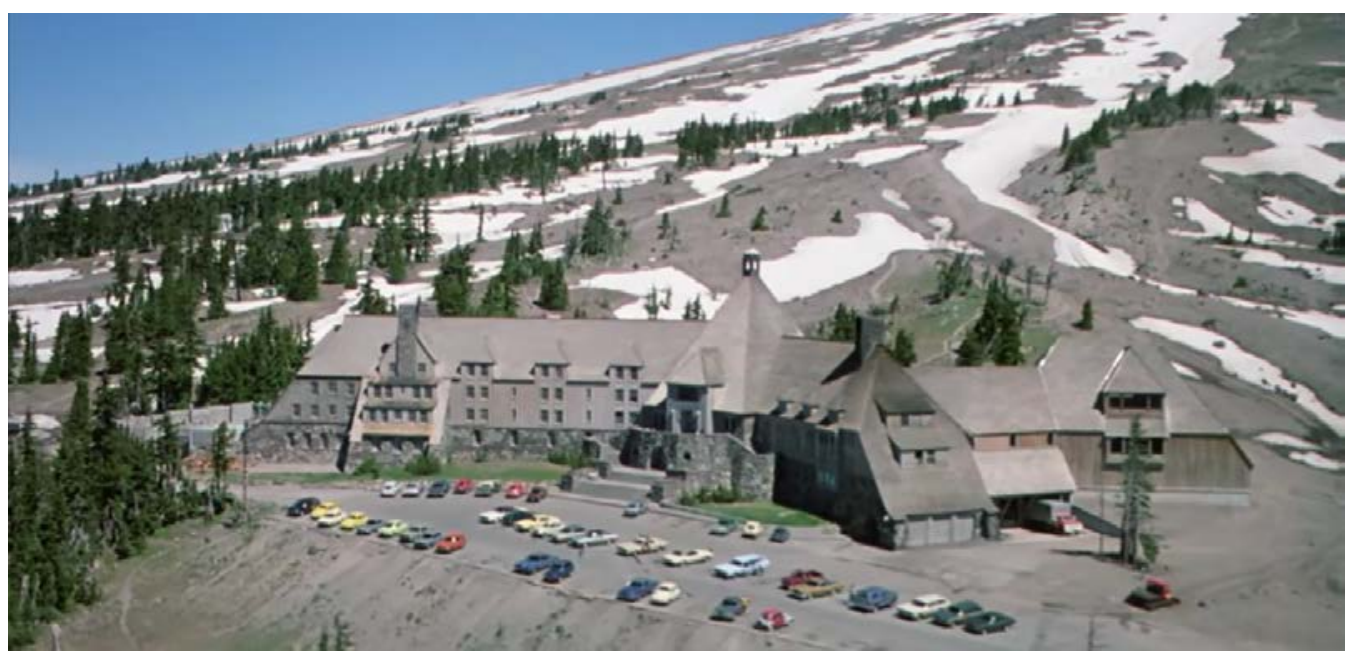

Şekil 1: Overlook Oteli (Kubrick, 1980) 
Jameson, The Shining hakkında yazdığı yazının bir bölümünde Overlook'un Jack karakteri üzerinde ne denli etkili olduğunu ve cinnete giden sıkıntılı yoldaki konumunu belirtmiştir (URL-1): “Overlook'un mekânları Jack'in yenilgisini ve başarısızlığını yansıtmaktadır. Otelin büyük steril mekânları, hızla çoğalan ve gerçek bir devamlılıkla birbirine bağlanan, serbest bırakmaktan çok çevreleyen ve sarıp kapatan, özgür kılmaktan çok önüne set çeken ve mâni olan mekânları -- bunların hepsi Jack'in akli ve ruhsal sıkıntı ve anlamsızlığını büyütür hale getiriyor."

Overlook Oteli, dev ölçekli, gösterişli fakat filme konu olduğu mevsimde içinde bekçi aileden başka kimsenin olmadığı boş bir oteldir. Overlook Oteli'nin hem şehirden izole olduğu hem de içinde sadece üç kişinin barındığı düşünülürse, The Shining, sinemadaki otel kullanımları arasında farklı bir yere sahiptir. Burada otel sadece filmin geçtiği herhangi bir mekân ya da dekor olarak değil, filmin en önemli unsurlarından biri olarak seyircinin karşısına çıkar.

\subsection{Lobi - sıkışmışlık}

Lobi, The Shining'de insan - mekân ölçek farkının en iyi okunabildiği hacimdir. Kubrick, lobide geçen sahnelerde mekânın devasa boyutu ve insanın bu hacim içinde kendini ne denli yalnız ve sıkışmış hissettiğinin anlatımını yapmıştır. Lobi, işlevsel olarak ele alınacak olunursa, insanların sosyal etkileşim için bulunduğu mekânlardan biridir. Bir otele girildiğinde işlevsel olarak ve konumu itibariyle kullanıcının ilk ulaştığı mekândır. Bu alanda yoğun bir eylemler serisi ve işleyiş gerçekleşir (Köseoğlu, 2004).

Lobi bir ortak kullanım alanıdır. Filmdeki gibi tek bir insanın kullanımı lobi için olağan bir durum değildir. Dolayısıyla Jack'in içinde bulunduğu gergin durum büyük ölçüde lobinin kullanımıyla izleyiciye yansıtıır. Jack, filmde çoğunlukla yalnız olduğu sahnelerde lobide görülür (Şekil 2). Mekânın bu psikolojik çöküş evresinin anlatımındaki etkisi yadsınamayacak kadar fazladır. Jack, içerisinde kaybolmuşluk hissine kapıldığı, normal kullanımında insan yoğunluğunun fazla olduğu ama anlatının geçtiği zaman zarfı içerisinde Jack'ten başka kimsenin olmadığı bir otelin lobisinde iken yalnızlığının vurgusu ancak mekân ile bu kadar etkili anlatılabilir. İnsanların yalnızlık, kaybolmuşluk ve sıkışmışlık hislerinin mekân üzerinden bir okuması Žižek tarafından yapılmıştır ve bu mekân - insan ilişkisini The Shining üzerinden anlatmıştır (Žižek 2011, ss.40): “Hepimizin bildiği üzere (Stepen King'in romanından uyarlanan) film, kışın kapalı olan geniş modern bir dağ otelinde geçer, otelde oranın bakımıyla ilgilenen bir aile yaşamaktadır. Bu basit durum olsa olsa zengin çağrışımları akla getirir: Japonya'da metro kalabalığında ezilip hala kendini başkalarından uzakta hissedebiliyorken, The Shining'de terk edilmiş geniş bir ev dahi bireyleri kendilerini sıkışmış hisseden ve agresiflik içinde köpüren tek bir aile için yeterince geniş değildir. Büyük otel açıkçası geçmişin ruhlarının uğrak yeri haline geldiği lanetli bir binadır."

The Shining'in mimari arka planı bu nedenle önemlidir. Patlak veren cinnet, filmde üç kişilik bir aile ile barındıkları dev boş yapı arasındaki gerilimle ve zıtlıkla anlatııı. 


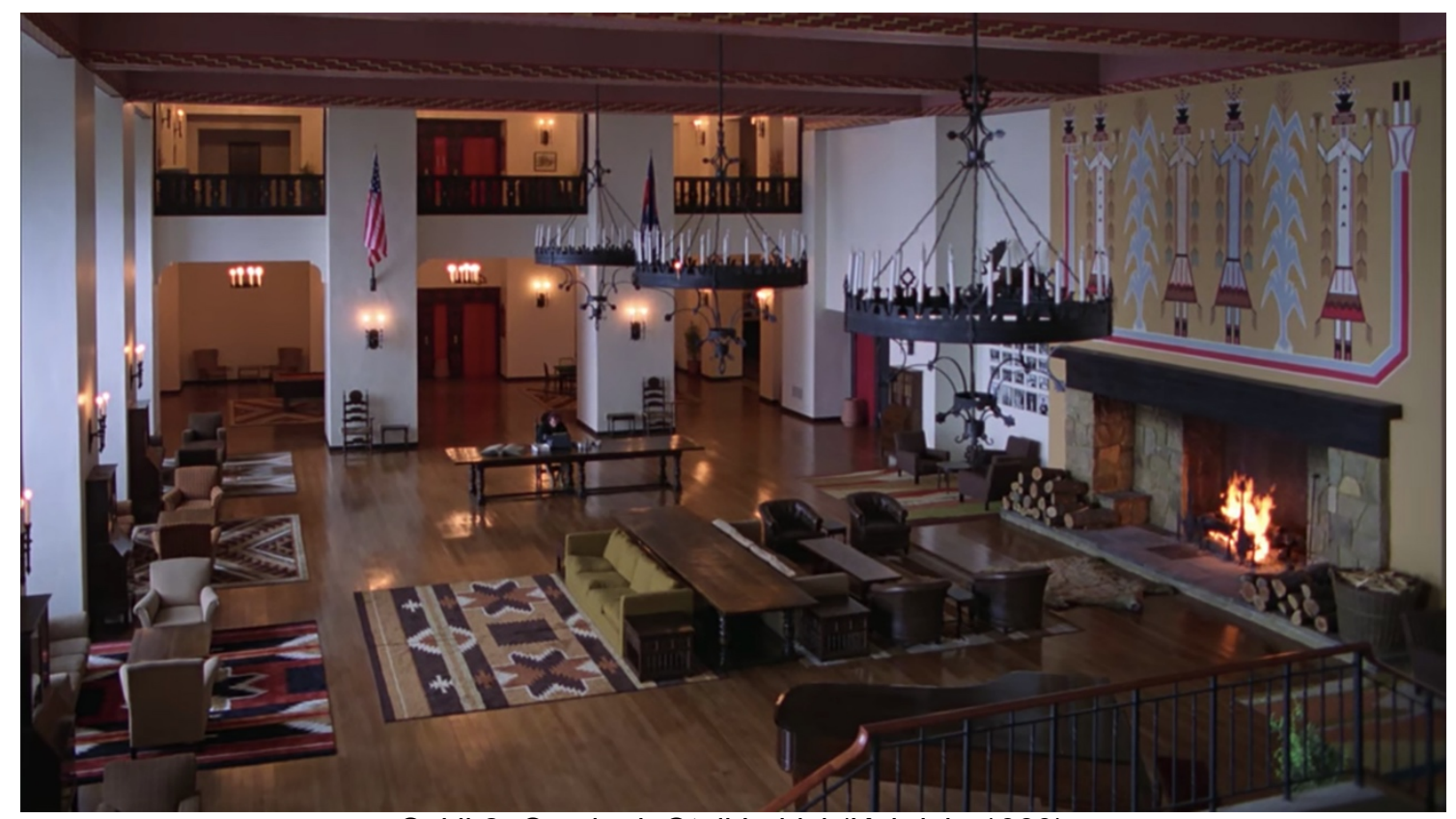

Şekil 2: Overlook Oteli Lobisi (Kubrick, 1980)

Lobilerin tavan yüksekliklerinin kullanıcılar üzerinde yarattığı etki, yüksekliklerinin fazla olduğu otellerde kişinin, başını yukarı kaldırmazsa tavanı göremediği ve bu durumun sınırlanmışlık hissini azalttığı yönündedir. Lobilerdeki tavan yüksekliğini geniş bir hacim oluşturmaya katkıda bulunur. Aynı zamanda, alçak tavanlı mekânların, kullanıcıya sıkıntı verdiği ve basık bir mekânda bulunmanın olumsuz etki yarattığı bilinmektedir. Çok yüksek tavanlı mekânların ferahlık hissi yarattığı ve sınırlanmışlık hissini azalttığı gözlemlenmiş olsa da tavan yüksekliğinin aşırı olduğu lobilerde hacmin boşluk hissi oluşturduğu ve en, boy ve yüksekliğin kullanıcı sayısıyla doğru orantılı olması gerektiği Köseoğlu (2004) tarafından belirtilmektedir. Bahsedilen bu 'boşluk' hissi ve bu hissin oluşturduğu psikolojik gerilimler filmde en etkili şekilde seyirciye lobi mekânlarında yansıtılmıştır.

Tekinsizlik olgusunun temel taşlarından 'simetri'nin kullanımı lobinin mekân olarak seçildiği sahnelerde de kolaylıkla okunmaktadır. Jack'in dev lobinin tam ortasında yer alan uzun masasının yine tam ortasına yerleştirdiği daktilosu ile romanını yazmaya çalıştığı sahne filmde mekânın simetrik kullanımına örneklerden biridir. Burada konsantre olmaya çalışan Jack, simetrinin Wendy'nin lobiye girmesi ile bozulmasının ardından birden hiddetlenmiş ve Wendy'i azarlayarak ileride cinnete varacak olan psikolojik şiddetinin ilk belirtilerini burada göstermiştir (Şekil 3). 


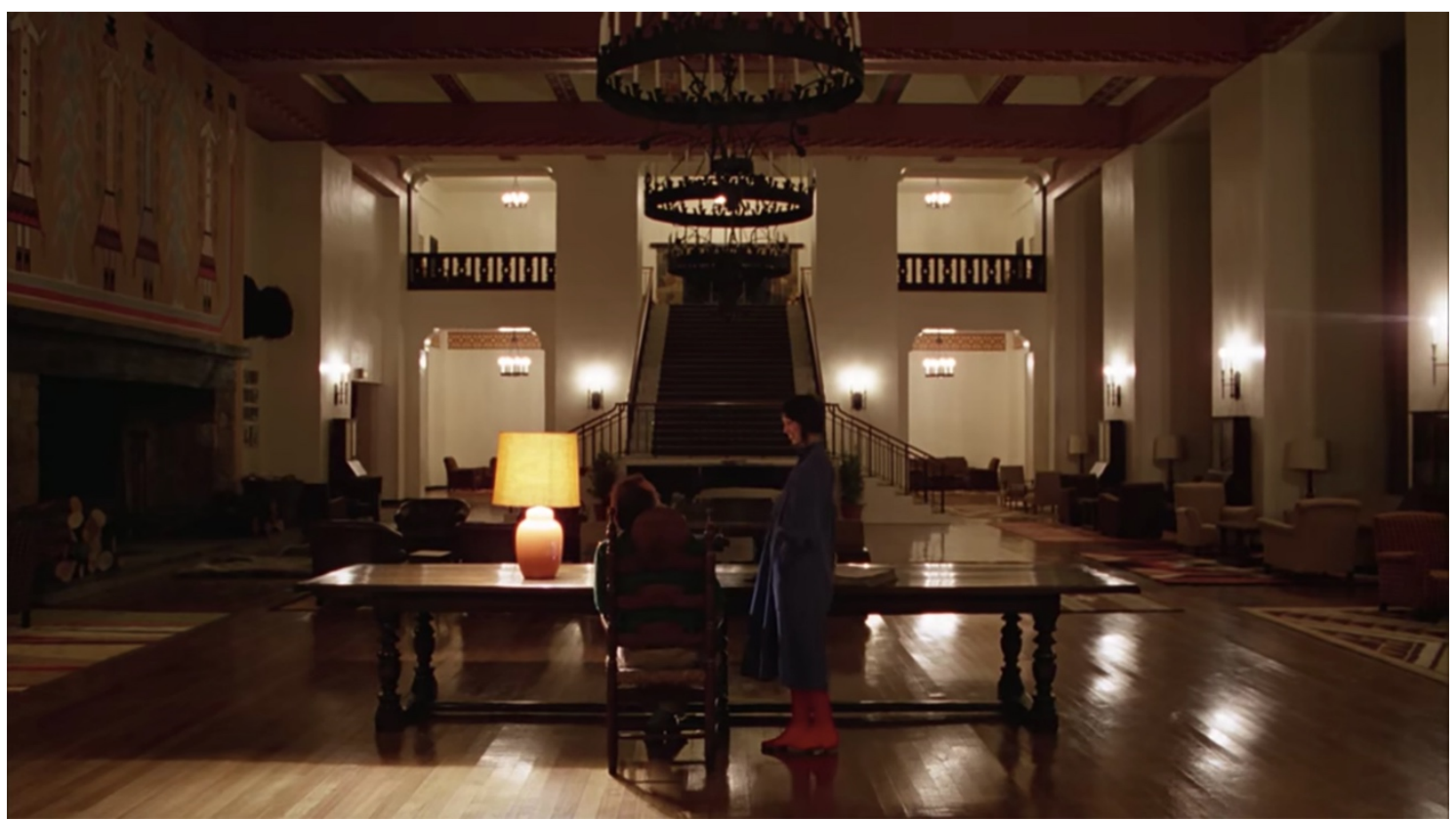

Şekil 3: Wendy'nin lobiye girişi (Kubrick, 1980)

Overlook Oteli'nin lobisi incelendiğinde mekândaki malzeme kullanımı ve dekoratif elemanların ortak dili göze çarpar. Yer kaplaması ahşaptır ve yerel motiflerden oluşan kilimler görülmektedir. Bu kilimler aynı zamanda duvarlarda da süsleme amaçlı kullanılmıştır. Geleneksel çizgiler kullanılarak tasarlanan lobi, o bölgenin kültürel değerleri ve öğelerini yansıtacak ya da çağrıştıracak şekilde oluşturulmuştur. Bu durum, bu mekânı, kavramsal ve anlamsal olarak bulunduğu bölgeye ait kılar (Köseoğlu, 2004). Lobide ağırlıklı olarak görülen geleneksel ve yerel dekoratif elemanlar filmin ilk sahnelerinde geçen bir konuşmaya da gönderme yapmaktadır. Overlook'un inşa edildiği alan tarihte yerlilerin katledildiği mezarlığın üzeridir. Filmin alt metninde hep bu katliamın doğurduğu vahşet bulunur.

\subsection{Koridorlar - tedirginlik}

Koridorlar, yapılarda ana mekânlar arası bağlantıyı sağlayan, insan hareketine rehberlik yapan uzun ve dar geçitlerdir. Fakat koridorlar her zaman mekânla açık bir ilişki oluşturmaz, bu nedenle kontrol altına alınamayan biçimlerde, yönelim bozukluğu yaratabilecek aldatıcı hacimler, yani labirentler yaratabilir. Kubrick'in filmdeki koridor kullanımı sadece mimari anlamda mekânları birbirine bağlama işlevinden çok sembolik ve psikolojik bir anlam taşımaktadır. Filmde koridor, otelin mimari gereksinimleri için bir ara mekân olmaktan çıkmış, otelin dev bir labirente dönüşmesi için kullanılmıştır. Filmde koridorlar açık ve net bir biçimde bir mekânı diğerine bağlamaz; tam tersi içinden çıkılmaz, köşe dönüldüğünde insanın karşısına ne çıkacağı bilinmeyen, tedirginlik ve kaybolmuşluk hissinin verildiği ve filmin çoğu karakteristik sahnesine anlam yükleyen ana mekânlardır.

Koridor, aynı zamanda Kubrick için perspektif algısının en etkili verilebileceği mekânlardır. Overlook'un ne denli büyük olduğu, geniş açılarla yapılan ve genel mekânların çekimleri ile koridorların bir ucundan diğer ucuna perspektifin etkin bir biçimde algılanabileceği çekimlerle izleyiciye yansıtılmıştır. Danny'nin bisikleti ile otelin koridorlarında yaptığı ve filmin en karakteristik çekimlerine sahne olan gezisi, aynı zamanda seyircinin de aynı göz hizasında otelde yaptığı bir gezintidir (Şekil 4). 


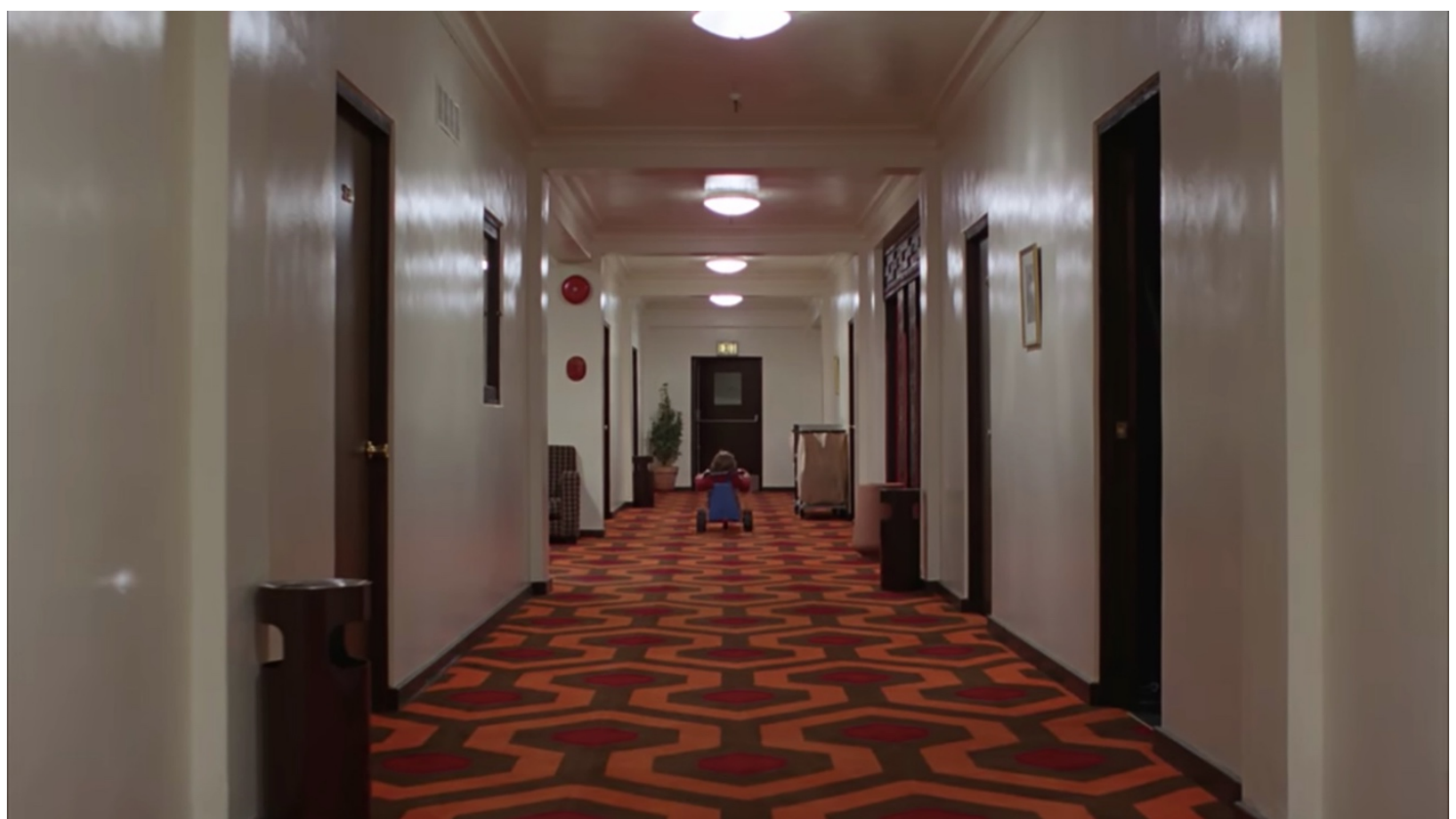

Şekil 4: Danny'nin koridor gezintisi (Kubrick, 1980)

Filmin karakteristik sahnelerinden biri olan ve tekinsizlik kavramının en önemli unsurları arasında yer alan 'ikizlik' olgusunun sahnelendiği 'ikiz kız kardeşler' sahnesine mekân olan da otelin odalara açılan bir koridorudur. Danny (ve izleyici) otelin odalara açılan koridorlarında gezerken, çiçek desenli duvar kağıtları ve halı kullanılan mekânda nihayet koridorun son bulmasıyla güvenilirlik duygusu oluşacakken birden koridorun ortasında ikiz kız kardeşlerin ortaya çıkmasıyla tekinsizlik duygusunun zirvesi olan gerilim doruğa ulaşır (Şekil 5).

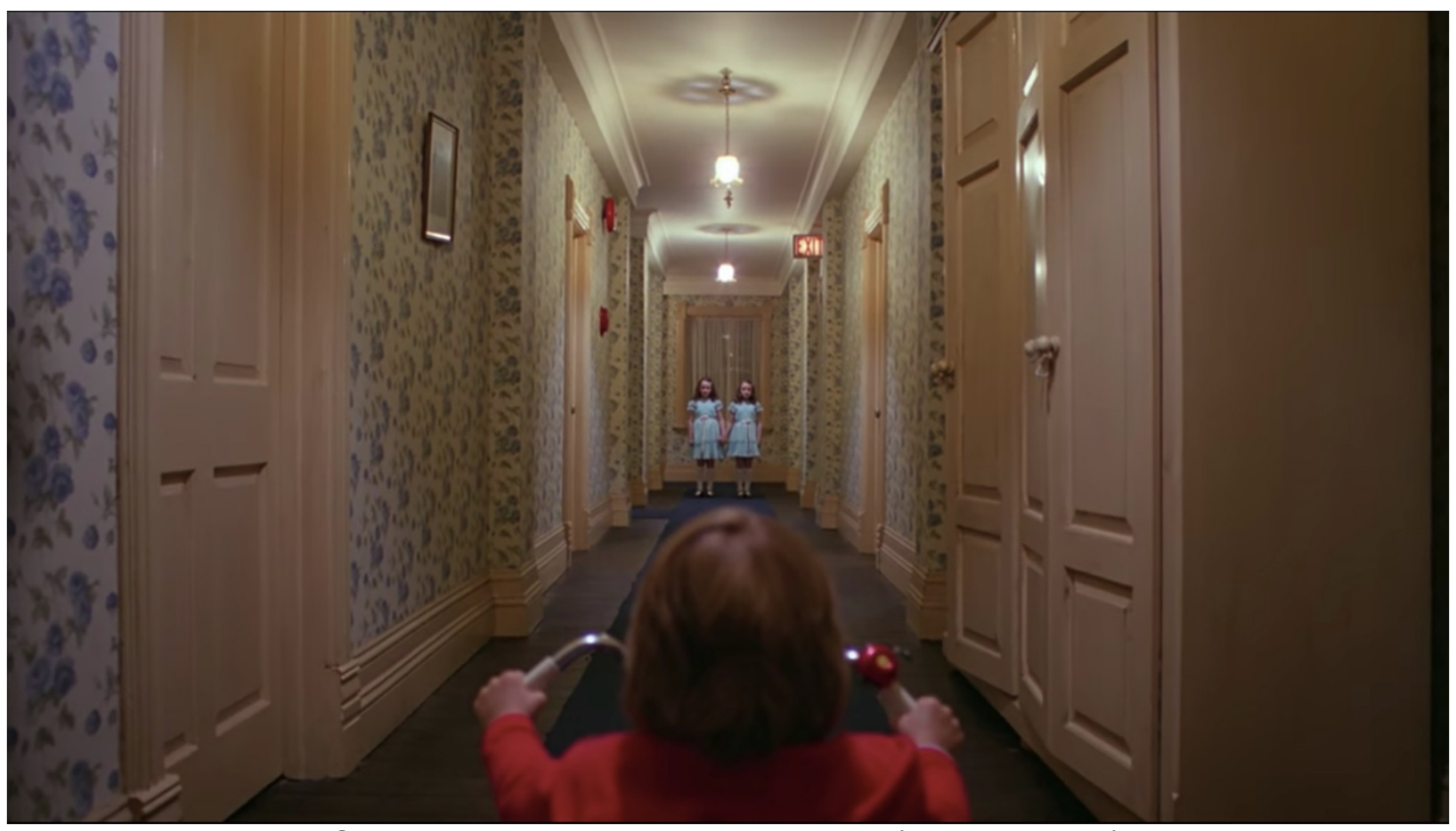

Şekil 5: Koridordaki ikiz kız kardeşler (Kubrick, 1980)

Burada ikiz kız kardeşler sadece Danny'nin değil, aynı zamanda seyircinin karşısına birden çıkmaktadır. Mekânda gezinti ile başlayan bu sahne, tekinsizlik olgusunun temel oluşturucularından biri olan 'ikizlik' olgusunun seyirci tarafından simetrik mekânda 
algılanması ile devam eder. Artık koridorlar kimse için güvenilir değildir. Koridorlar her an ikiz kız kardeşlerle karşılaşılabilir tekinsiz mekânlardır.

Kubrick'in gerilimi artırmak ve tekinsizliğe vurgu yapak için kullandığı bu anlatım, ikizlik olgusunun özünde var olan anlatım gücü nedeniyle birçok sanatçı tarafından kullanılmıştır. The Shining'de karşımıza çıkan ikiz kız kardeşler daha önce Diane Arbus (1967) tarafından çekilen bir fotoğraf ile paralel okunabilir. Arbus, çektiği fotoğrafların ortak bir dili olması ile öne çıkmıştır. Kubrick'in ikiz kız kardeşleri, Arbus'un ikiz kız kardeşleri ile aynı görsel anlatım dilinde buluşurlar. İkisi de tekinsiz bir durum yaratır (Şekil 6).
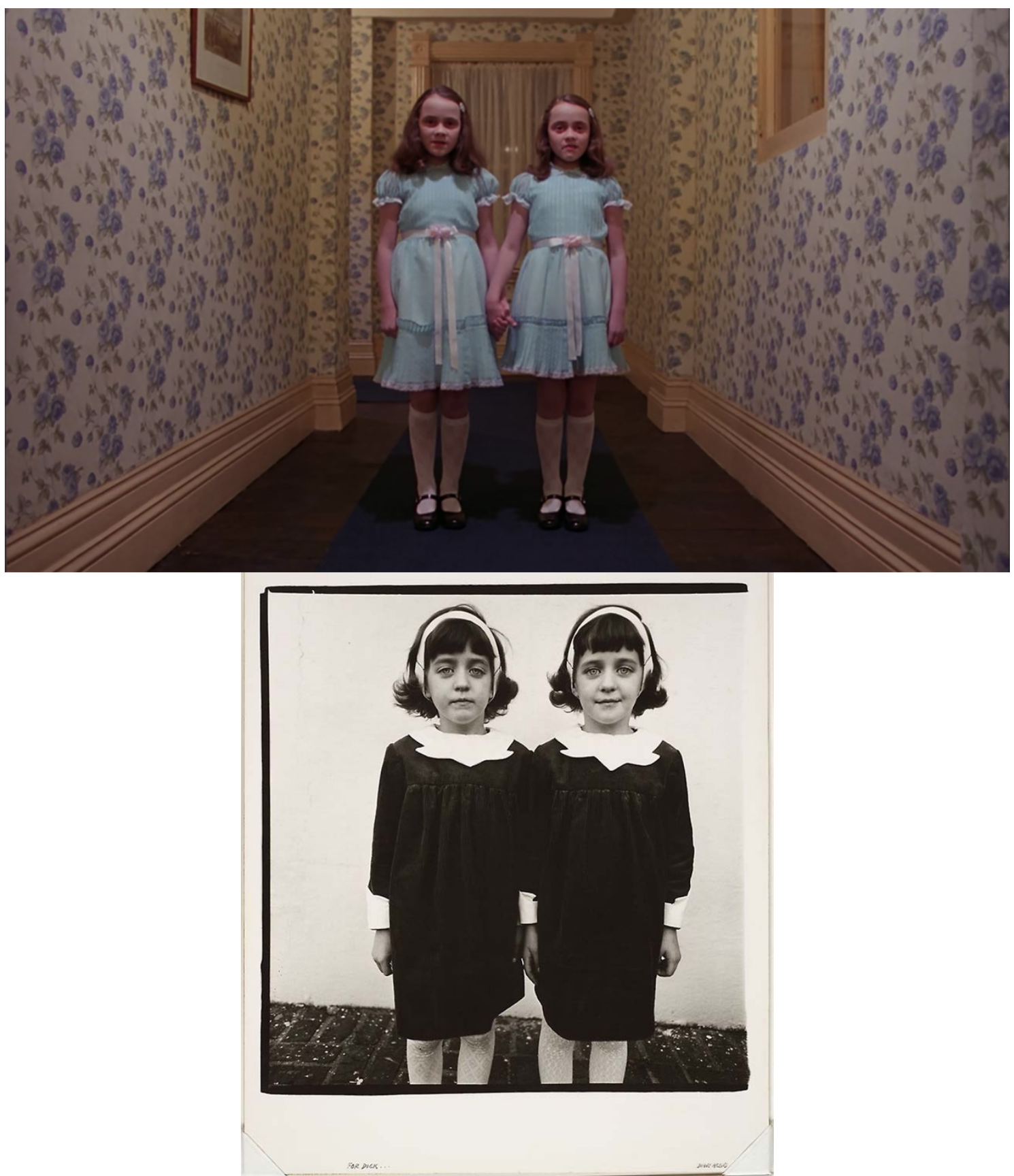

Şekil 6: Üstte ikiz kız kardeşler, altta Arbus'un çektiği fotoğraf (Üst, Kubrick, 1980. Alt, URL-2) 
'İkizlik' (double), Freud'un 'tekinsiz' kavramını açıkladığı eserinde, tekinsizlik olgusunu oluşturan tanıdıklık, düzen, tekrar gibi temel unsurlardan biridir. 'Íkizlik' en net biçimde bu koridor sahnesinde seyirciye yansıtılmıştır, fakat Kubrick bu olguyu biçimsel olarak ele aldığı bu sahne dışında filmde birçok defa metaforik olarak da kullanmıştır. Otelin dışında yer alan dev labirent ve lobideki maketi, güvenilir baba Jack ve cinnet geçiren canavara dönüşen baba Jack, Redrum ve Murder kelimeleri bu kullanımların öne çıkan örnekleridir. İkiz olma durumu mekân üzerinden okunduğu zaman simetriye ulaşılmış olur. Filmde bu durum, karakterler üzerinden anlatıldığı gibi, mekân üzerinden yoğun bir vurgu ile sağlanmıştır. Bu, sahnelerin merkez çizgisi ele alındığında ikiz mekânlar oluşturması ile sağlanmıştır. İkizlik olgusunun mekândaki yansımasının 'simetri' ile sağlandığı görülür.

Filmde simetri ikiz mekânlar yaratılarak kullanıımıştır. Tasarımda ve matematikte birden çok çeşidinin bulunduğu simetri filmde 'yansıma simetrisi' olarak izleyicinin karşısına çıkar. Simetrinin en etkili olduğu sahneler olan koridor sahneleri yansıma eksenine Danny yerleştirilmiş ve elde edilen ikiz mekânlar simetrinin kusursuz bir işlenmesi olarak değerlendirilebilir. Simetrinin, koridorlardaki hacimsel ve mimari anlatımının yanında otelin (özellikle koridorlardaki) halılarının örüntülerindeki kullanımı filmin önemli karelerinin oluşumunda büyük rol oynar. Danny'nin otelin odalarına açılan halı üzerinde oyuncakları ile oynadığı sahne (Şekil 7), simetrinin rahatsı edici derecede kullanımına en iyi örneklerdendir.

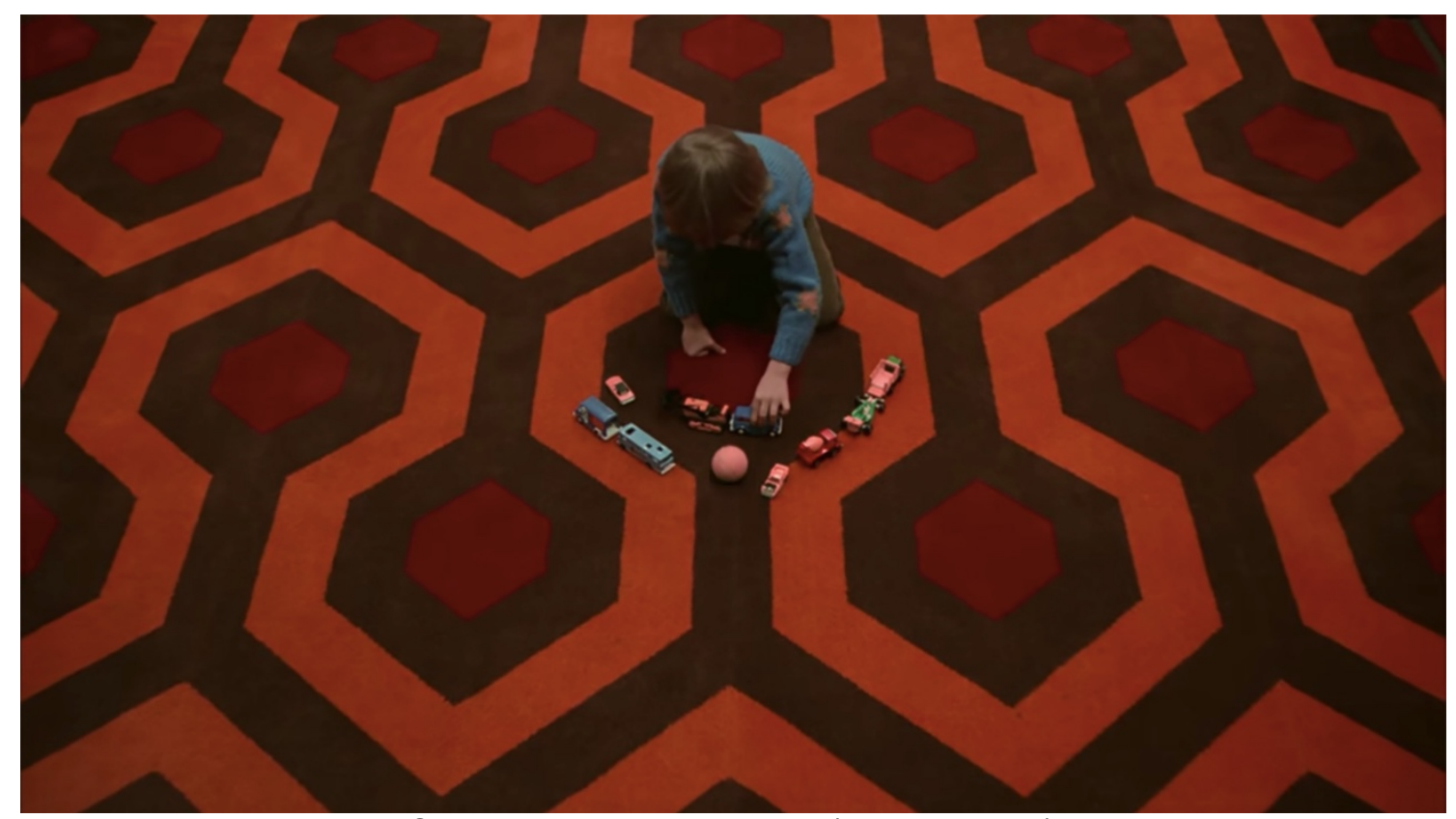

Şekil 7: Danny halıda oynar (Kubrick, 1980)

Burada halının örüntüsünün mükemmel derecede simetrik olması ve Danny'nin bu örüntünün merkez noktasında yer alması, hatta dahası bir topun hayali bir el tarafından örüntünün merkez ekseninden Danny'e doğru yavaşça atılması gerilim ve tekinsizlik olgusunun simetri ile anlatıldığı en önemli sahneyi oluşturur.

\subsection{Torrence Ailesi'nin odası - güvensizlik}

Otel odaları, insanların otelin genel mekânlarındaki sosyal ortamdan uzaklaşıp kendi dünyalarına çekildikleri, mahremiyetlerinin sembolü olan, otelde konaklayacakları süre boyunca onların 'ev'i görevini üstlenecek olan mekânlardır. The Shining'de Torrence 
Ailesinin odası, konakladıkları sadece uyumak için kullandıkları bir mekândır. Çünkü filmde ailenin tüm evi otelin tamamıdır. Zaten filmde işlenen psikolojik gerilimin ve insan-mekân ölçeğinin zıtlığı bir aile için fazla büyük ve boş olan otelden kaynaklanmaktadır.

Oda tekinsizlik olgusunun özü olan 'ev' kavramının işlendiği mekândır. Odanın, Torrence Ailesi için 'ev'i sembolize ettiğinden oteldeki en güvenilir mekân olması beklenir. Fakat Kubrick mekâna eklediği tek bir olgu ile tüm odayı / evi tekinsiz hale getirmeyi başarmıştır. Mekânda kullanılan bu öğe aynadır. Aynanın hem mekân derinliği açısından sahip olduğu potansiyel hem de metaforik kullanımı bu odayı güvenli bir sığınaktan, içinde canavar kötücül ikizlerin dolaştığı tekinsiz bir mekân haline getirmektedir.

Ayna hem araya mesafe koyan hem de somutlaştıran, aynı zamanda hoş olmayan bir gerçeği ortaya çıkartan, birçok sanat alanında kullanılan bir motiftir. Merleau-Ponty (2006) aynayı "şeyleri görüntülere, görüntüleri şeylere, beni başkasına, başkasını bana dönüştüren evrensel sihrin enstrümanı" olarak tanımlamıştır (s.43). Merleau-Ponty'nin tanımı aynanın yansıtması, derinlik yaratması, ikiz oluşturması gibi özellikleri sanattaki kullanımının neden bu denli geniş olduğunu açıklar niteliktedir.

Sinemada aynanın The Shining'deki kullanımına paralel olarak olumsuz anlamlar yüklenerek kullanımı çoğunluktadır. Ayna, yansıttığı karedeki öğelerin bilinmeyen bir tarafı olduğunun yani 'öteki'nin belirtilerini taşır. Filmde ayna cinnet merkezli bir cinayetin habercisidir. Danny'nin Jack'ten beklediği güvenin arayışlarının konu alındığı sahne Torrence Ailesi'nin oteldeki mahrem mekânı olan odalarında seyirciye sunulmuştur (Şekil 8). Jack' in her sözü güven telkin etmektedir fakat odaya hâkim olan gerilim, Jack'in bakışları, Jack ve aynadaki canavar ikizi bu güvende tekinsiz bazı izler olduğunu seyirciye yansıtır.

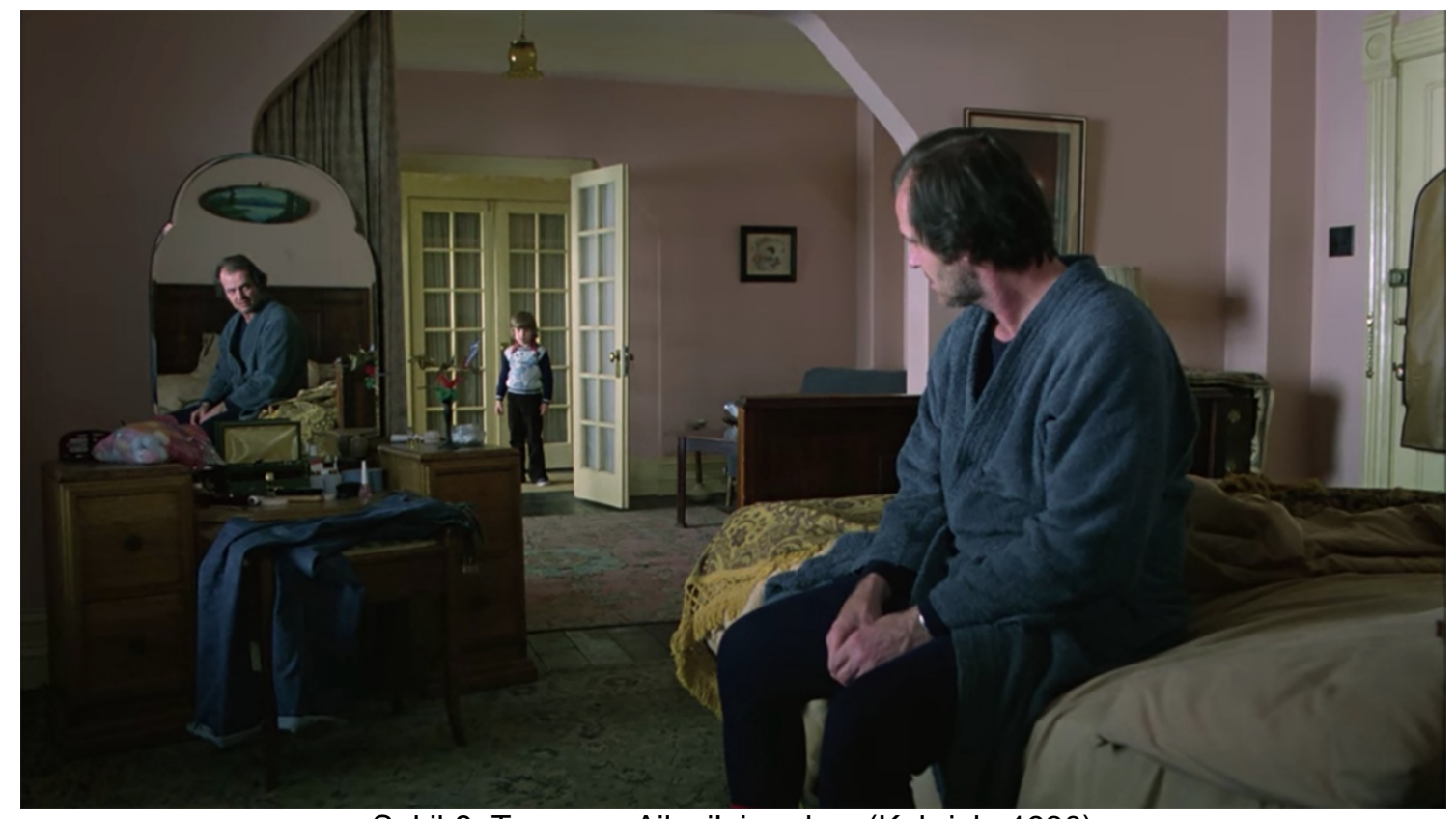

Şekil 8: Torrence Ailesi'nin odası (Kubrick, 1980)

Jack'in aynaki yansıması, filmdeki canavar ikizine gönderme yapar. Ayna kullanımının en yoğun olduğu mekân ailenin odasıdır. Aynanın kullanımının mekânsal derinliğin yaratılması açısından önemli olduğu kadar tekinsizliğin temel unsurlarından biri olan ikizliğe metaforik anlamda bir gönderme yaptığı için de önemlidir. Ailenin odasında 
Jack'in canavar olan diğer yüzü hep aynalar ile seyirciye verilmiştir. Filme hâkim olan tekinsizlik olgusunun temel taşlarından biri olan 'ikizlik'in ayna ile seyirciye aktarıldığı sahneler odada geçmektedir. Buna verilebilecek en belirgin örnek ise Kubrick'in ailenin otele henüz yerleşmişken sabah kalktıklarında Wendy'nin Jack'e getirdiği kahvaltının asal görüntüsü yerine ayna görüntüsünü tercih etmesidir (Şekil 9).

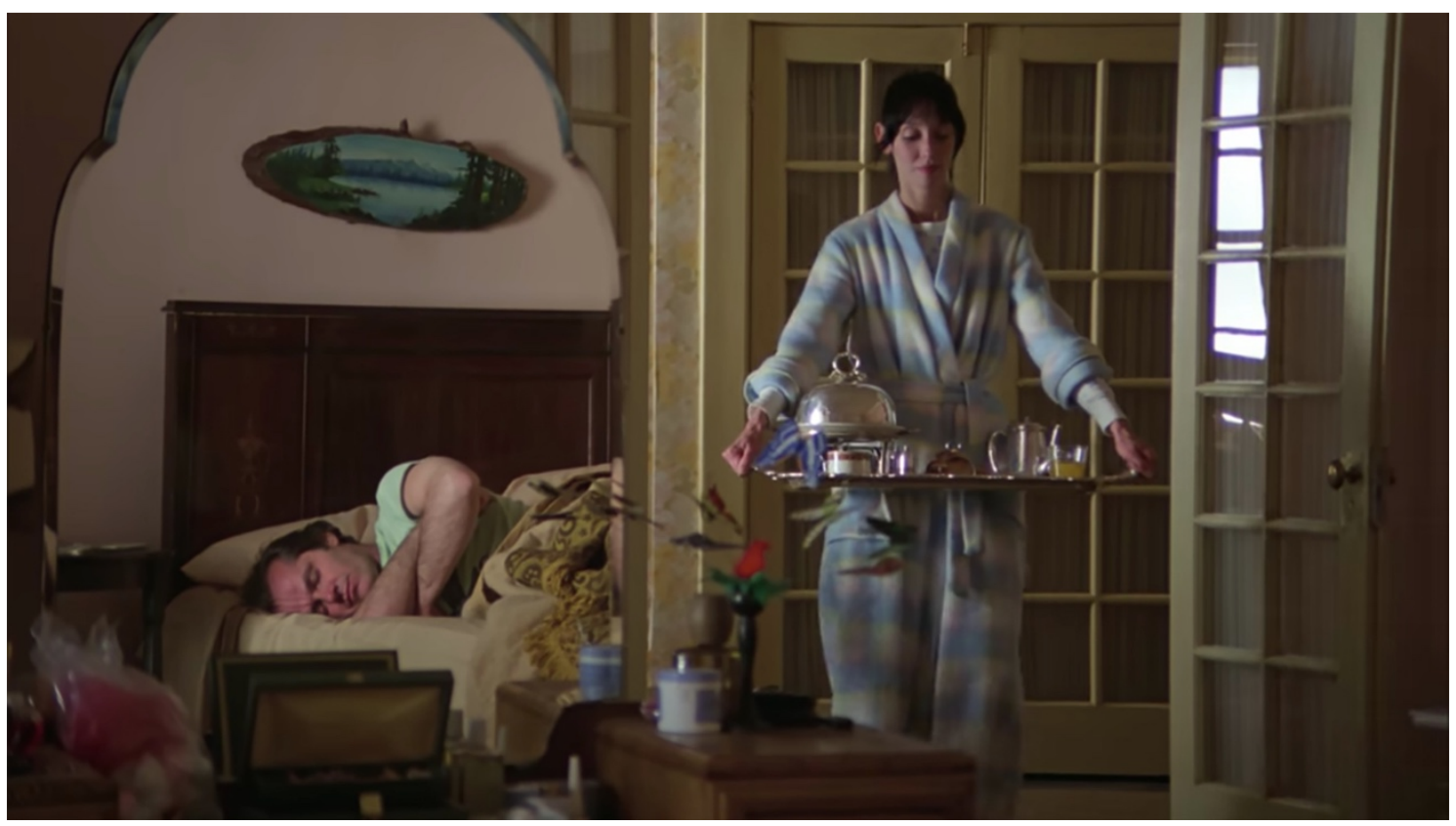

Şekil 9: Odada ayna kullanımı (Kubrick, 1980)

Kubrick aynayı bu şekilde kullanarak hem seyircinin mekân algısı ile bir oyun oynar hem de mekânı hangi açıdan çekerse çeksin ifade edemeyeceği bir perspektif yakalar. Sahnede hem Wendy'nin ifadeleri hem de ona cevap veren Jack'in yüzü aynı anda seyirciye sunulmaktadır. Karakterler ile sağlanan bu anlatım mekân için de geçerlidir. Hem odanın girişi hem de aynı mekânın seyircinin arkasında kalan kısmı aynı karede görülmektedir. Aynı zamanda ayna, yönetmenin çerçevelediği mekân içinde bir çerçeve daha yaratarak asal mekân içerisinde bir de sanal mekân oluşturur. Bu kullanım ile aynanın özünde var olan asalının ikizini yaratma The Shining'de görsel anlatımı oldukça zenginleştirmiştir.

Kubrick'in filmde aynayı kullandığı ve ailenin odasında geçen sahnelerden biri de Danny'nin odadaki ayna aracılığı ile Wendy'e yolunda gitmeyen bir şeyler olduğunu anlatmaya çalışmasıdır (Şekil 10). Danny kapıya bir yazı yazar: REDRUM! Wendy'nin bu yazıyı okuyabilmesi için yazının aynaya yansıması gerekir. Aynaya yansıyan bu yazının 'cinayet' anlamındaki MURDER olduğu görülür. Kubrick, filmde ikizliği çoğunlukla görsel anlatı ile izleyiciye yansıtsa da bu örnekte olduğu gibi harflerden oluşan sembolik anlatımlarla da desteklemiştir (Nelson, 2000). Danny, babasının uzun süre önce fark ettiği tekinsiz halini yine bu tekinsizliğin filmdeki en büyük anlatıcısı olan ayna aracılığı ile iletir. 


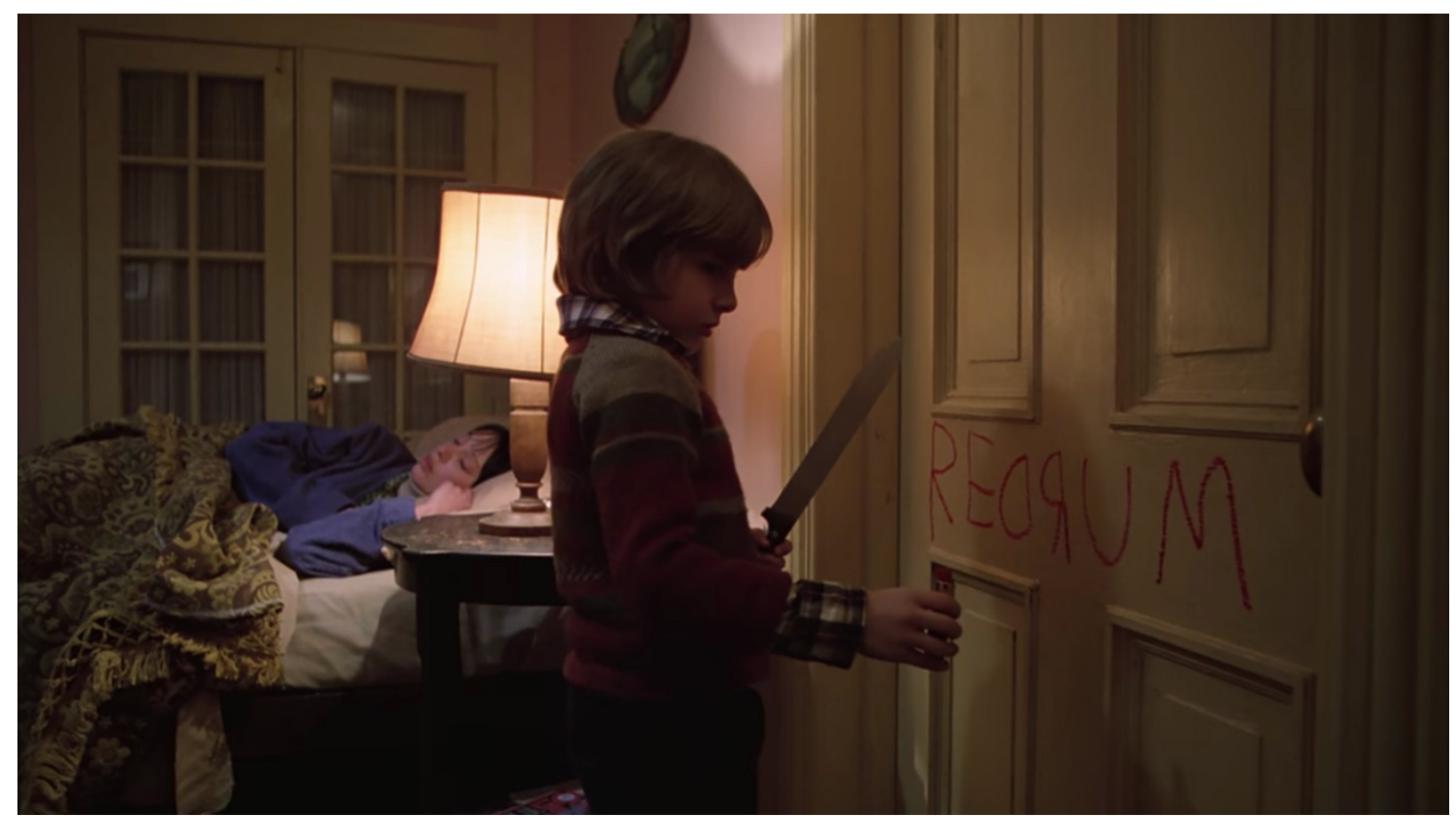

Şekil 10: Redrum (Kubrick, 1980)

Odanın içerisinde yer alan banyo ise filmin afişi için seçilen karenin görüntülendiği mekân olmuştur. Filmin başında her şeyin dingin ve güvenilir olduğu odada Jack, cinnetinin son noktasına ulaşır ve Danny ile Wendy'i elindeki balta ile öldürmek için o 'ev'i sembolize eden tekinsiz odada anne ve oğlu banyoya sıkıştırır ve kapıyı balta ile parçalayarak içeri girmeye çalışır (Şekil 11).

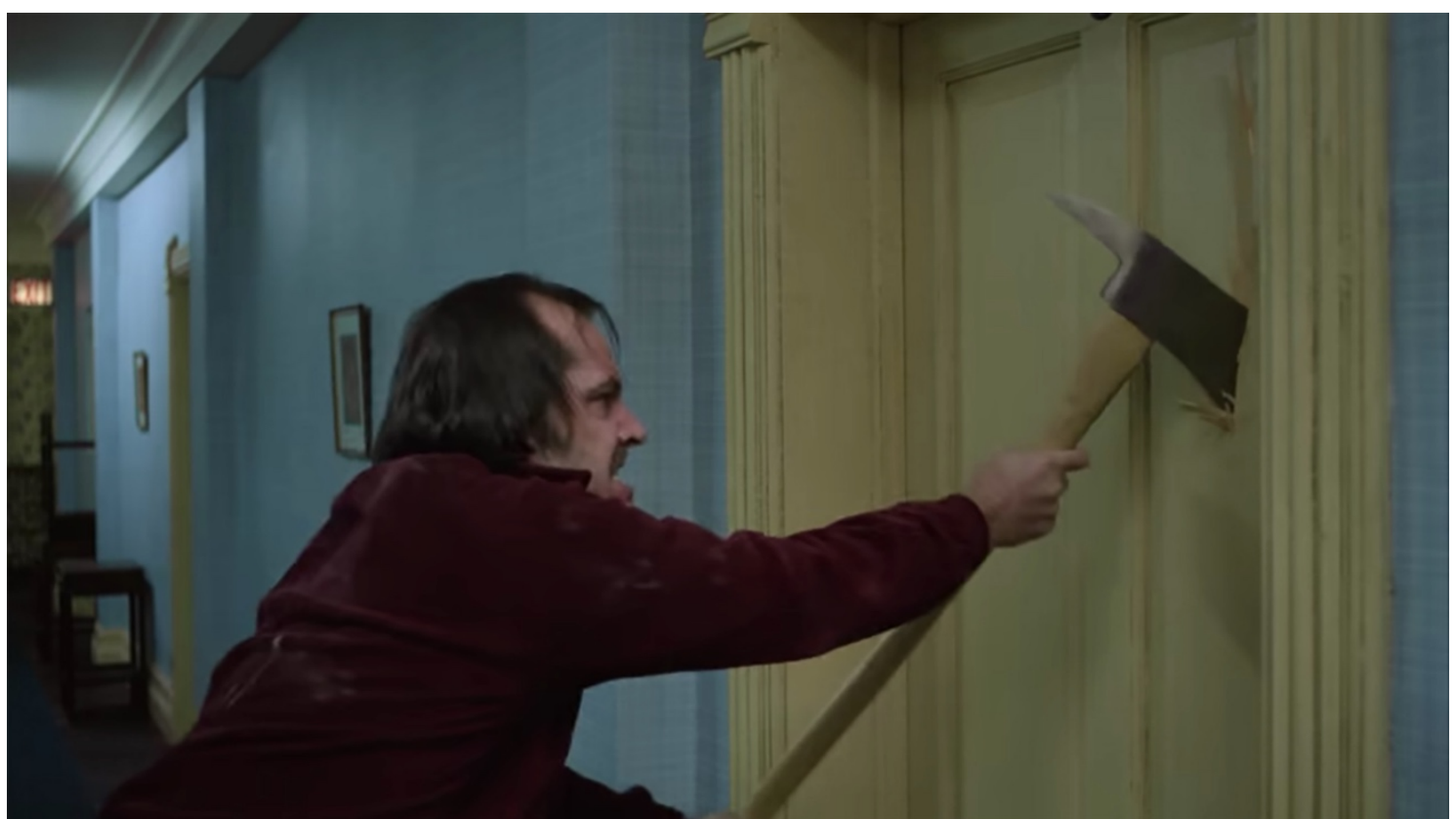

Şekil 11: 'Here's Johnny!' (Kubrick, 1980)

Kubrick'in, sinema tarihinde tartışmasız önemli bir yeri olan bu sahnedeki başarısını, oyunculuk ve mekânının dramatik aksiyona olan büyük etkisine bağlamak mümkündür. Dev otelde cinnet geçiren baba, eşi ve oğlunu otelin en güvenilir olması beklenen, oteldeki 'ev'leri yani odalarında sıkıştırmış, küçücük bir mekâna hapsetmiş ve tek çıkış olarak düşündüğü kapıya da elinde baltası ile dayanmıştır. Bu sahne, filmin genelindeki gerilimin nihayet yerini korkuya bıraktığı sahnedir. Kubrick'in daha önce yaptığı gibi 
seyirciyi filmdeki karakter ile birlikte mekânda var etmesi bu sahnede de açıkça görülmektedir. Wendy ile birlikte seyirci de bu küçük mekâna sıkışmıştır. Danny banyonun küçük penceresinden çıkıp kaçmış fakat seyirci ve Wendy banyoda köşeye kıstırılmıştır.

\subsection{Asansör - belirsizlik}

Filmin ilk sahnelerinden birinde Overlook Oteli'nin müdürünün Torrence Ailesini otelin dış mekânında gezdirirken otelin eski bir Kızılderili mezarlığının üzerine inşa edildiğinden bahseder. Burada Amerika'nın, Kızılderililer'in katliamından sonra kanlı temeller üzerine inşa edilmiş olması şeklinde bir okuma yapılabilir. Lobideki yerel motifler ile süslenmiş kilimler ve lobinin otelin diğer mekânlarına kıyasla baskın bir şekilde bölgenin katliamdan önceki toplumunun simgelerini taşıyan unsurlar göze çarpar. Otelin eski bir mezarlık üzerine inşa edilmesine yapılan bu gönderme, filmin yine ilk sahnelerinden biri olan ve ilerleyen dakikalarda kurgudan bağımsız şekilde tekrar eden asansör sahnesi ile devam eder. Asansörün kapıları kapalıyken, içinden boşalan kan şelalesi, gözardı (overlook) edilmiş bir tarihe göndermedir. 'Kan'ın kapalı kapılar ardından yavaşça ve şiirsel bir şekilde boşalması başı başına seyircide gerilim yaratır. Asansör sahnesinin filmdeki ilk gösterimi henüz gerilim unsurlarının aleni bir biçimde seyirciye verilmediği sahnelerdir. Bu yüzden seyirci birden karşısına çıkan bu kan seline bir anlam veremez. Anlam veremediği gibi rahatsızlık duyar çünkü kan başı başına tedirgin eden bir unsurdur. Bu gerilim sahnenin film içinde tekrarlaması ile tekinsizliği zirveye taşır. Tekinsizlik kavramın özünde de var olan 'tekrar' mimaride ve sahnelerin görsel imajlarında sıkça kullanılmıştır. Tekrar kavramı pekiştirici rol oynar. Filmde tekrarlanan asansörden boşalan kan sahnesi (Şekil 12), kurgudan bağımsız kullanılması ile metaforik anlamların düşünülmesine ve yolunda gitmeyen bir şeyler olduğuna, dolayısıyla seyircinin bu belirsizliğin yarattığı tekinsiz bir durumu sezmesine yol açar.
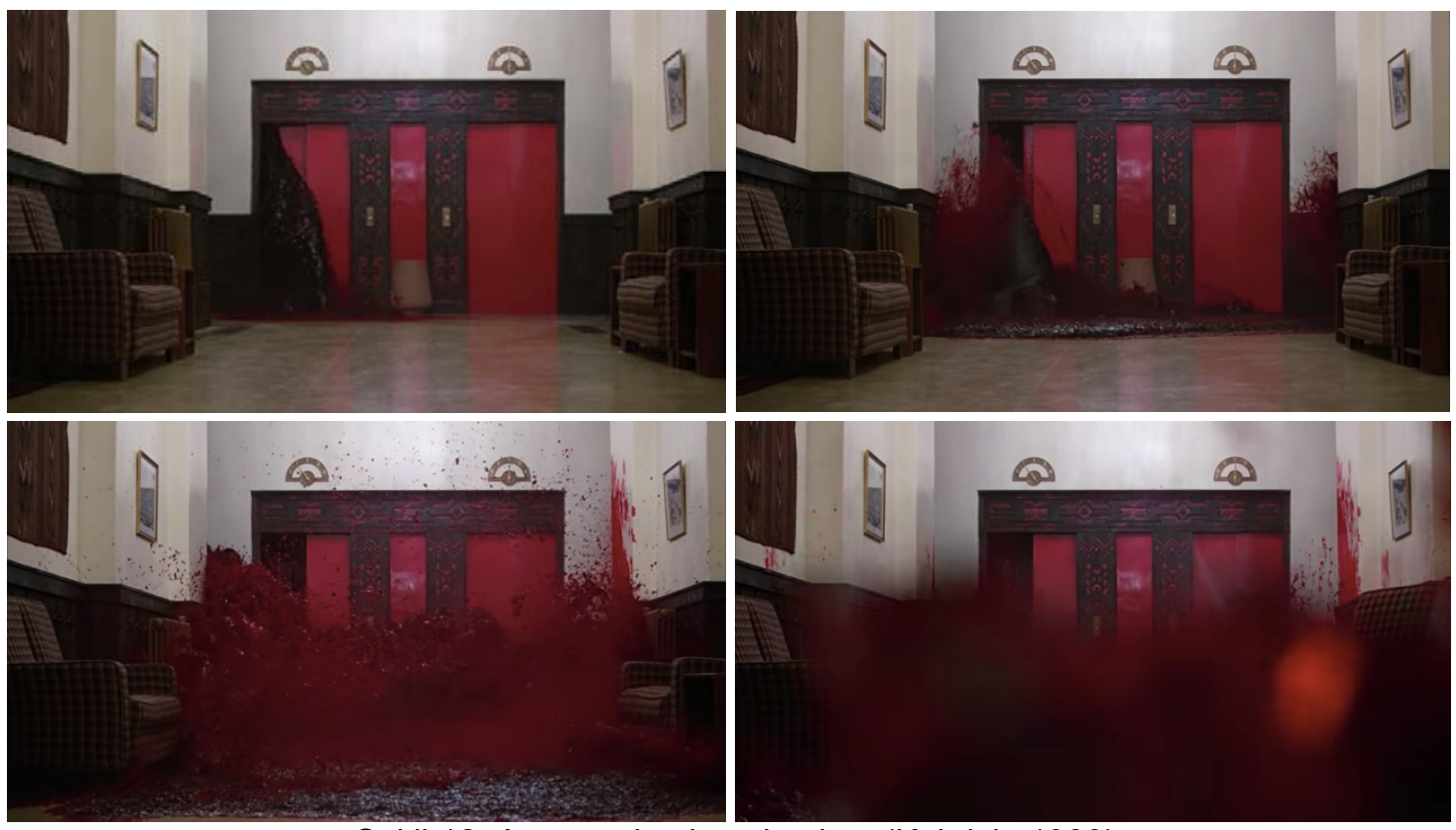

Şekil 12: Asansörden boşalan kan (Kubrick, 1980)

Asansör sahnesinin gerilim yaratmadaki etkisi başlı başına sadece bir kan seli olmasına bağlamak yanlış olur. Sahneyi etkileyen 'tekrar' gibi önemli unsurların yanında kanın herhangi bir yerden değil de bir asansör kapısından boşalması yaratılan 
gerilimin temel belirleyicisidir. Asansörün çağdaş mimarideki önemi yadsınamaz işlevi ve insanların alt bilinçlerindeki yeri incelendiğinde yapılardaki dikey sirkülasyonu sağlayan salt işlevsel bir öğe olarak kalmadığı görülmektedir.

Asansör, 'elektrikle işleyen, çelik halatla çekilen ve genellikle dik raylar arasında hareket eden, yapılarda insanları, yukarıya çıkarmada, aşağıya indirmede kullanılan araç' olarak tarif edilmektedir. Fakat insan beyninde yarattığı imgelem bu teknik tanımın ötesinde var olur. İnsanın zekâsı ile yaratığı her şey, teknik ile giderdiği her zorluk sonucunda her zaman güvenilir sonuçlar doğurmaz. Sinemada, özellikle yine Kubrick'in işlediği teknik olanın tekinsizliğinin ilk örnekleri belki de asansör ile insan hayatına girmiştir. Günümüz teknolojisi ile birçok elektronik alet gündelik hayata girmiş ve sinemacılar bu aletlerin ilk izlenimleri olan hayatı kolaylaştırma gibi işlevlerinin yanında insan kontrolünden çıkma gibi olguları filmlerinde çokça konu edinmişlerdir. The Shining'deki asansör sahnesi işte tam da bu bahsedilen insan kontrolünden çıkmış işlevsel yapı elemanının filmin başlıca karakteristik sahnelerinden birini oluşturmuştur.

Asansör beklenirken içinden kimin ya da neyin çıkacağı bilinemez, bilinmediği gibi az sonra içine girilip onun kontrolünde insan bedeni çoğu zaman olduğunun aksine ve gerginlik yaratan hatta bazen kimisi için korkutucu bir biçimde dikey harekete geçer. Klostrofobinin en sevdiği mekânlardan biri asansördür. Hızla ve kuvvetle düşme korkusunun en gizlice ve derinden hissedildiği en küçük iç hacimdir. İçinde yapılan yolculuk eğer güvenli bir şekilde sonuçlanırsa istenilen mekâna ulaşılacak, fakat o gerilim içeren belirsizlik hissi gerçek olursa içinde hapis kalınacak, belki birden düşecek belki de bir daha içinden çıkılamayacaktır.

The Shining'de asansörü bekleyen izleyicidir, Kubrick, filmdeki hiçbir karakteri bu sahnede kullanmaz, çoğu kez de yaptığı gibi seyirciyi özne yerine koyar. Asansörün kapısı yavaşça aralandığında ise beklenen asansörden çıkan (boşalan) bir oda dolusu kan selidir. Bahsedildiği üzere bu denli gerilim içeren mimari bir öğenin Kubrick tarafından yerli katliamına yaptığı gönderme ile bağdaştırarak kullanılması kan ve tekrar gibi diğer gerilim imgeleri ile desteklendiğinde sahnenin tekinsiz vurgusunun nedenini açıklar.

\subsection{Labirent - kaybolmuşluk}

Labirentin filmdeki kilit mekânlardan biri olmasının ve neden bu denli etkileyici bir mekân olduğunun araştırması yapıldığında labirentin tarihte eski bir yeri olduğu görülmektedir. MÖ. 400lerde Girit sikkelerinin üzerinde görülen labirent formu (Şekil 13) resimden müziğe, mimariden edebiyata sayısız çeşitlerle günümüzde de hala etkisini sürdürmektedir. Bu form karşımıza ilk olarak Yunan mitolojisinde çıkmaktadır. Kral Minos'un emrinde çalışan mimar Daedalus, labirentin yaratıcısı ve labirenti mitolojiye sokan kişi olarak bilinir. Mimar, yarı-boğa yarı-insan bir canavar olan, kötülüğün ve vahşetin sembolü Minotaurus'un hapsedildiği bir labirent tasarlamıştır.

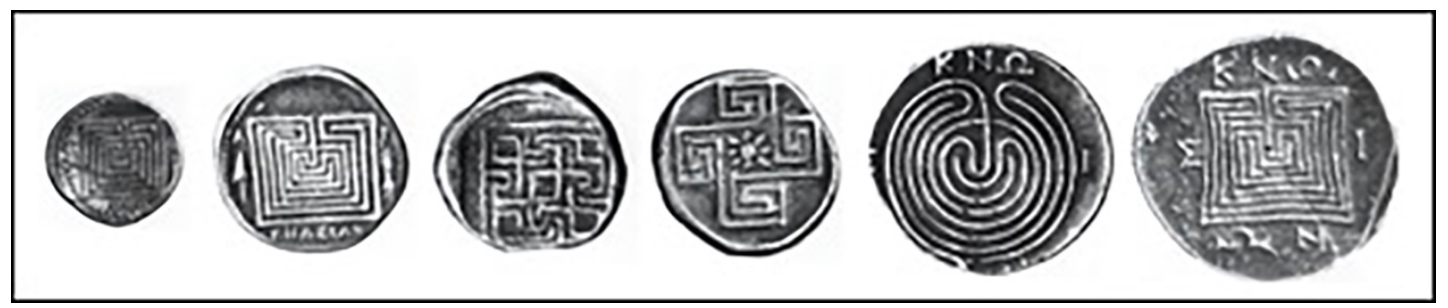

Şekil 13: Labirent desenli Girit sikkeleri (URL-3) 
Bu mit ve labirent formu zaman içerisinde birçok sanat eserinin içeriğini oluşturmuştur. Mimari mekânlarda hem form hem de metaforik açıdan kullanılan labirentler, fiziksel mekânlarda, kullanıcıyı doğru yol konusunda yanıltıp amaç noktasına ulaşmasını geciktirir. Aynı zamanda labirentin içinde iken labirentin tümünü tasvir etmenin imkansızlığına vurgu yapar (Pekol, 2010).

Mitolojik anlamı ve tarif edilmeyi imkânsız kılan, sürekli kararsızlık ve rahatsızlık yaratan yanı ile labirent, Kubrick'in filmde tüm bu anlam derinlikleri ile kullandığı bir mekândır. Labirentin filmde ilk olarak görüldüğü kısım, anne ve Danny'nin hava almak ve oteli tanımak amaçlı gezisinin olduğu kısımdır (Şekil 14). Burada aksiyon açısından durağan bir durum söz konusudur, fakat filmin özü olan tekinsizlik labirentin de doğasında var olduğu için, filmin ileriki sahnelerinde gerilim ve şiddetin doruk noktaya ulaşacağı mekân haline geleceği seyirci tarafından hissedilir. Çünkü belirtildiği gibi labirent tekinsizliğin, sıkışmışlığın, çaresizliğin sembolüdür aynı zamanda. Filmde labirentin tanıtıldığı sahne anne ve Danny'nin gezintiye çıktıkları 'normal' bir gündür. Fakat bu 'normal' durumu mekânın kendisi, sadece formu sayesinde 'normal olmayan' tuhaf bir gün haline, tuhaf bir gezintiye dönüştürmektedir. Çünkü labirentte, hiçbir yönlendirmenin olmadığı bu ortamda biçimler erimekte, ölçek yok olmakta, derinlik ve yüzeyler yanıltmaktadır.

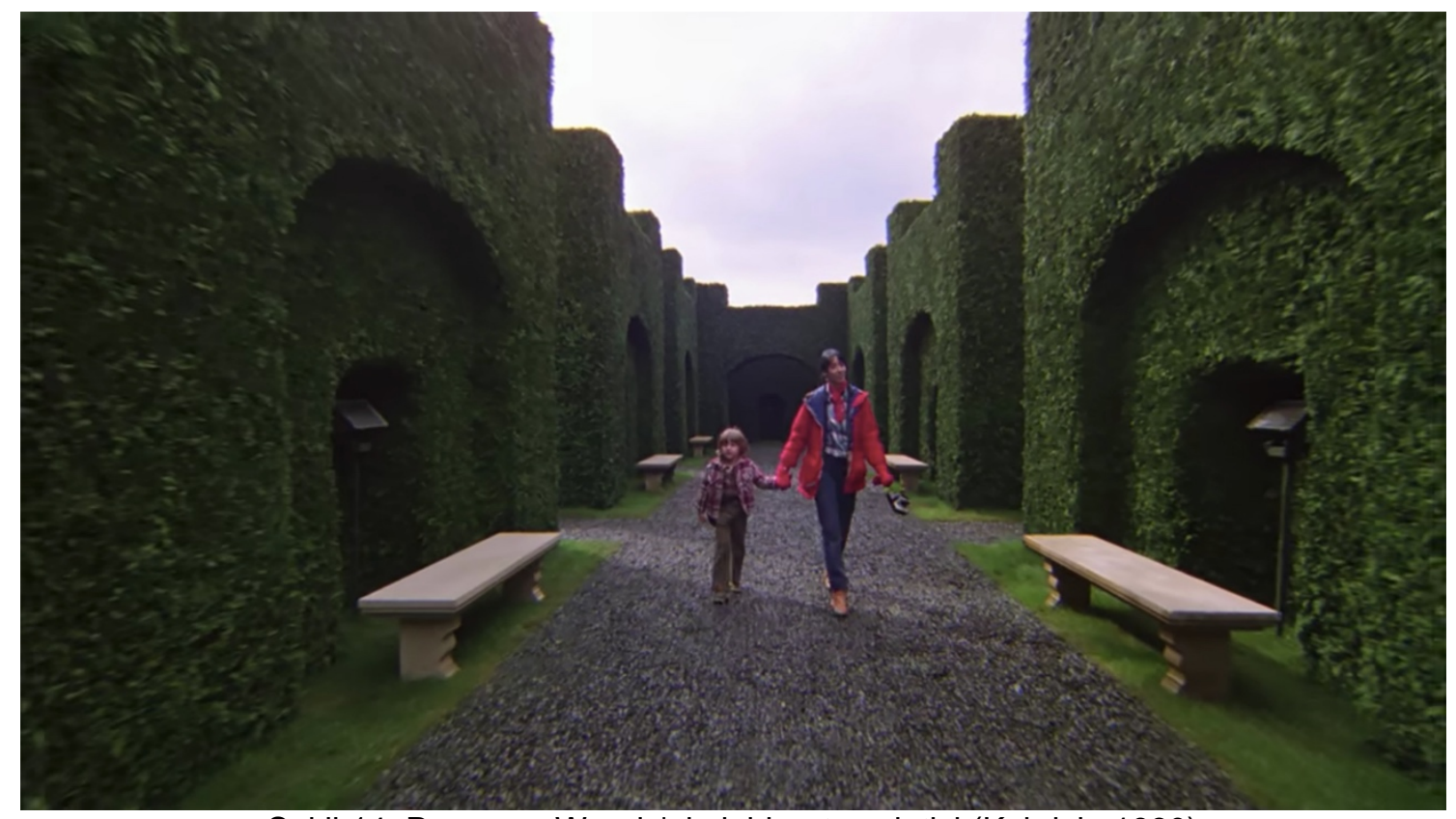

Şekil 14: Danny ve Wendy'nin labirent gezintisi (Kubrick, 1980)

Anne ve Danny'nin gezintiye çıktıkları sahnede, labirent içinde gezinen anne ve oğul ölçeğinden, labirent maketine odaklanmış dikkatlice inceleyen baba ölçeğine geçiş (Şekil 15), birbirine bağlı ve zekice bir illüzyon ile seyirciye aktarılmıştır. Burada dış mekândaki labirentin ikizi, birebir aynısı olan otelin lobisindeki maketidir. Sahne güneşli normal bir günde, normal bir gezintiyi konu alsa da mekânın yani labirentin bu normalliği en yüksek derecede tekinsiz ve gergin bir sahne haline getirdiği görülür. Bu 'normal' günde zararsız görünen labirent aslında özünde pek de zararsız bir mekân değildir. Labirent, içine hapseden bir mekândır. 


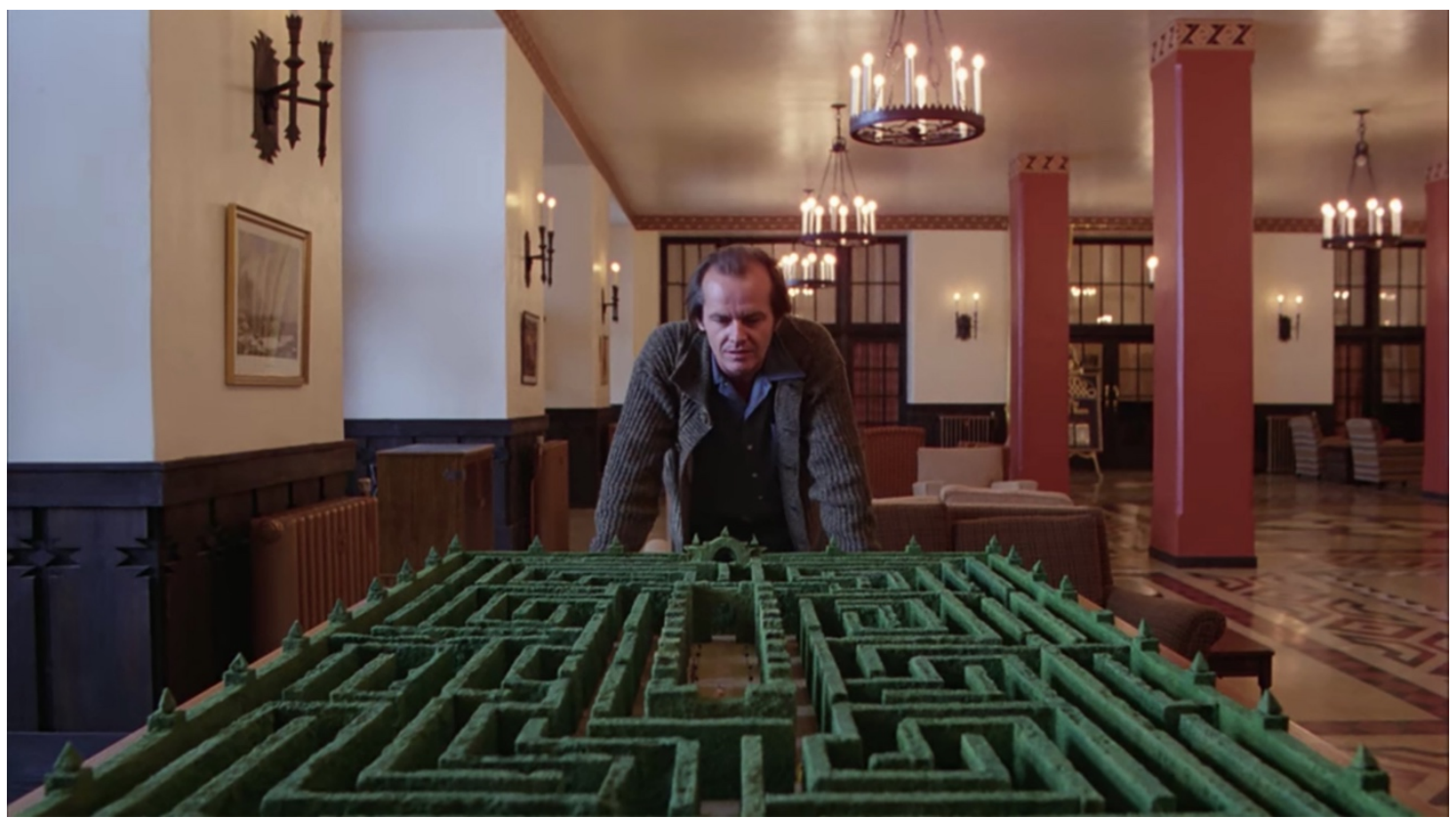

Şekil 15: Jack'in labirent maketini incelemesi (Kubrick, 1980)

Labirent mimari anlamda, insanların iki farklı ölçekte düşünebileceği bir mekândır. Bu iki farklı ölçek mekânın algısı açısından hayati önem taşır. Biri içinde bulunulduğunda duvarları yüksek, koridorları sağa sola keskin biçimde kıvrılan, içinden çıkılamaması için tasarlanmış, gerilimin, paniğin, sıkıntının adeta mekânlaştırılmış halidir. Diğeri tüm labirente hâkim olacak ölçekte olunduğunda karmaşık, çözümlenemeyen bir algı yaratır. Bu iki farklı ölçek de filmde işlenmiştir. Bu iki ölçeğin aynı zamanda tekinsizlik olgusunun en temel esaslarından biri olan ikizlik olgusu ile labirentte kullanıldığı görülmektedir.

Filmde labirent, gerilimin doruk noktasına ulaştığı, cinnetin bir cinayet ile sonuçlanmasının beklendiği son sahnede yer almaktadır. Bu son sahne de bu önceden izleyiciye tanıtılan labirentte geçmektedir. Cinnet geçirmekte olan baba Jack'in elinde bir balta ile oğlu Danny’i öldürmek için takip eder. Burada Danny labirentin içinde kaçmakta, Jack ise kovalamaktadır. Sahnede mekân olarak labirentin seçilmesinin önemi açıkça görülmektedir. Bu sahnenin açık, dolambaçsız, duvarları olmayan ya da çözümlenmesi kolay, temel bir plandan oluşan bir mekânda çekildiği düşünülecek olursa, gerilimin neredeyse sıfıra ineceği yadsınamaz. Labirent yani mekân burada aksiyonun temel belirleyicisi haline gelmiştir. Kubrick'in filmde labirent kullanımı, yaratıcılığının kısırlığı, doyumsuzluğu, kopukluk hissi ve mekânın psikolojik baskıları ile cinnete sürüklenen bir baba olan Jack'i, efsanevi ve sonsuz bir figür olan Minotaur'a dönüştürmesine ve filme efsanevi bir derinlik ve anlam vermesine olanak sağlar. Final sahnesinde ise artık Jack açıkça labirentteki öfkeli bir boğa-adama dönüşmüştür. Bu boğa-adam Picasso'nun (1935) La Minotauromachie adlı gravüründeki Minotaur tasviri ile birebir örtüşmektedir (Şekil 16). 

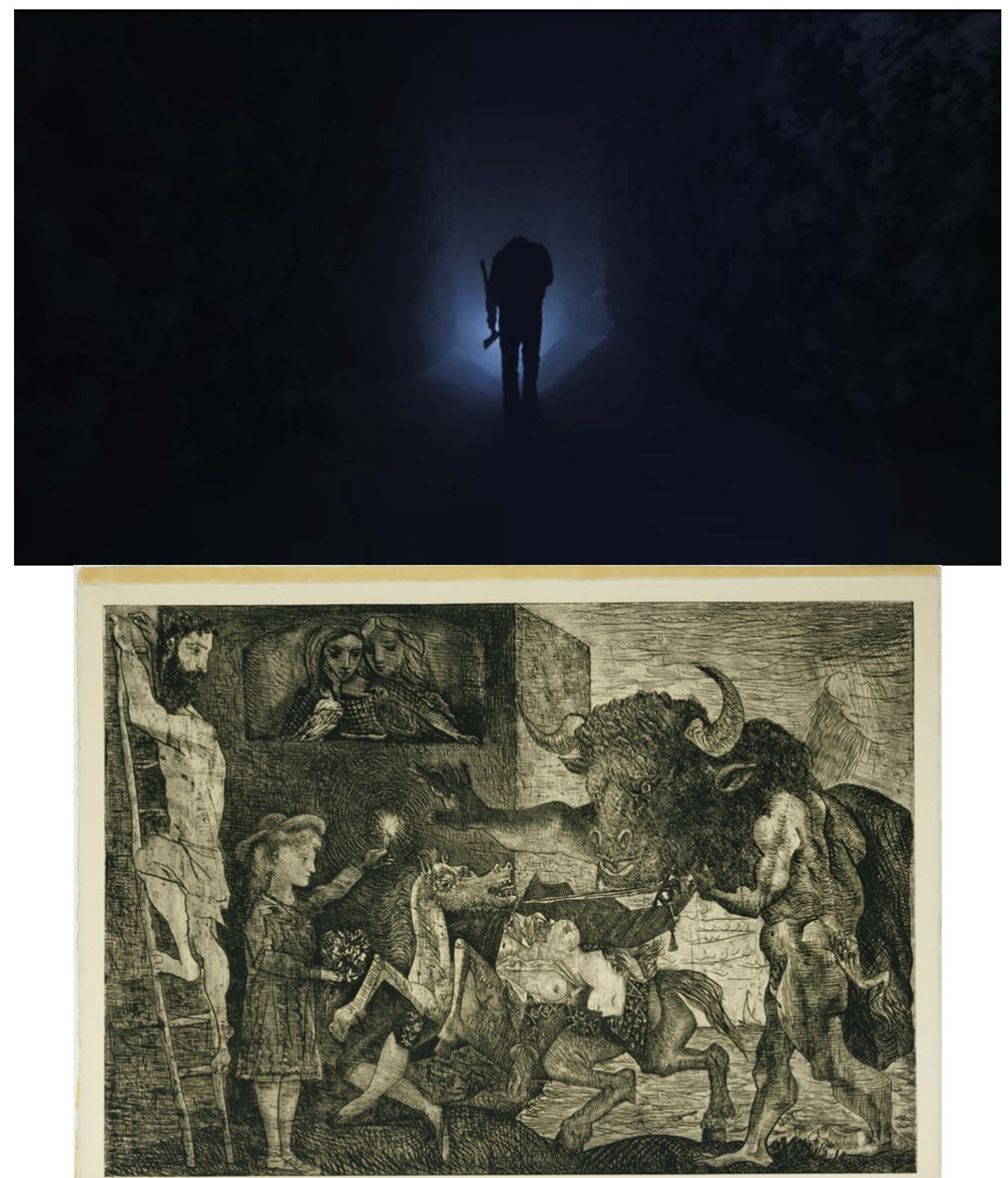

Şekil 16: Üstte Labirentteki Jack, Altta Picasso'nun Gravürü (Üst, Kubrick, 1980. Alt, URL-4)

Baba figürü labirentteki Minotaur'a dönüşümü aracılığı ile vahşi bir eş ve oğul katiline dönüşmektedir. Bu, tanıdık olanın öteki, normal olanın tuhaf ve yabancıya psikolojik bir dönüşümüdür. Filmdeki ilk küçük kızgınlık ve hırs belirtisinden itibaren, Jack' in yüz ifadesi ve kambur duruşu da giderek canavarlaşan bir özellik taşımaktadır.

\subsection{Merdiven - panik}

Mimari yapılarda dikey sirkülasyonun sağlandığı birimlerden biri olan merdiven, filmlerde olayları barındıran ve doruk anların yaşandığı mekânlar olarak yer alır. 
Doğasında var olan dikey formu, tırmanma, yükselme, artma gibi olguları içinde barındırmasına olanak sağlar. Bu özelliği, filmlerde dramatik aksiyonu desteklemek ve güçlendirmek amaçlı kullanılmasının başlıca nedenidir.

Merdivenin filmlerdeki kullanımı, yapısındaki grafik özelliğine bağlı olarak kare içinde görsel zemin sağlar. Bu, aksiyonun durağan ve sahnenin sabit kamera ile çekimi için söz konusu olan kullanımı için geçerlidir. Fakat aksiyon, giderek artan bir gerilim, heyecan, duygu yoğunluğu temeline oturuyorsa, kamera karakterleri takip ederek mekân içinde hareket eder ve mekândaki genel kullanım olan yatay hareket dışında dikey harekete de geçer. Bu ise seyircinin mekânı tam anlamıyla hacimsel olarak algılamasına ve içerisinde dolaşmasına olanak sağlar.

Kubrick, filmde mekânı aksiyonun belirleyici temel unsuru olarak kullanmasının yanı sıra, sahnenin aksiyonunu, atmosferini ve vermek istediği duyguyu desteklemek amaçlı da kullanmaktadır. Kubrick, bir yapının hacimsel gelişiminin vazgeçilmez unsuru ve aynı zamanda iç mimarinin temel parçası olan merdivene sadece mimari bir anlam yüklemez, aynı zamanda mecaz ve öyküsel anlatı açısından önemli bir rol yükler (Usai, 1998). Bunun en etkili örneği Jack'in psikolojik gerilimini ilk defa dışarı yansıttığı sahne olan merdivende geçen sahnedir. Burada anne, Jack'in psikolojisinde yolunda gitmeyen durumlar olduğunu fark eder ve elindeki beysbol sopası ile kendini korurken bir yandan da Jack'den uzaklaşmaya, kaçmaya başlar (Şekil 17). Bu sahnenin geçtiği mekâna bakılacak olunursa, mekân, yavaşça ve artan bir ivme ile tırmanan gerilimi destekleyici biçimiyle, sıfır kotundan basamaklar çıkıldıkça yavaşça yükselen, otelin lobisinden odalarına çıkan ana merdivendir.

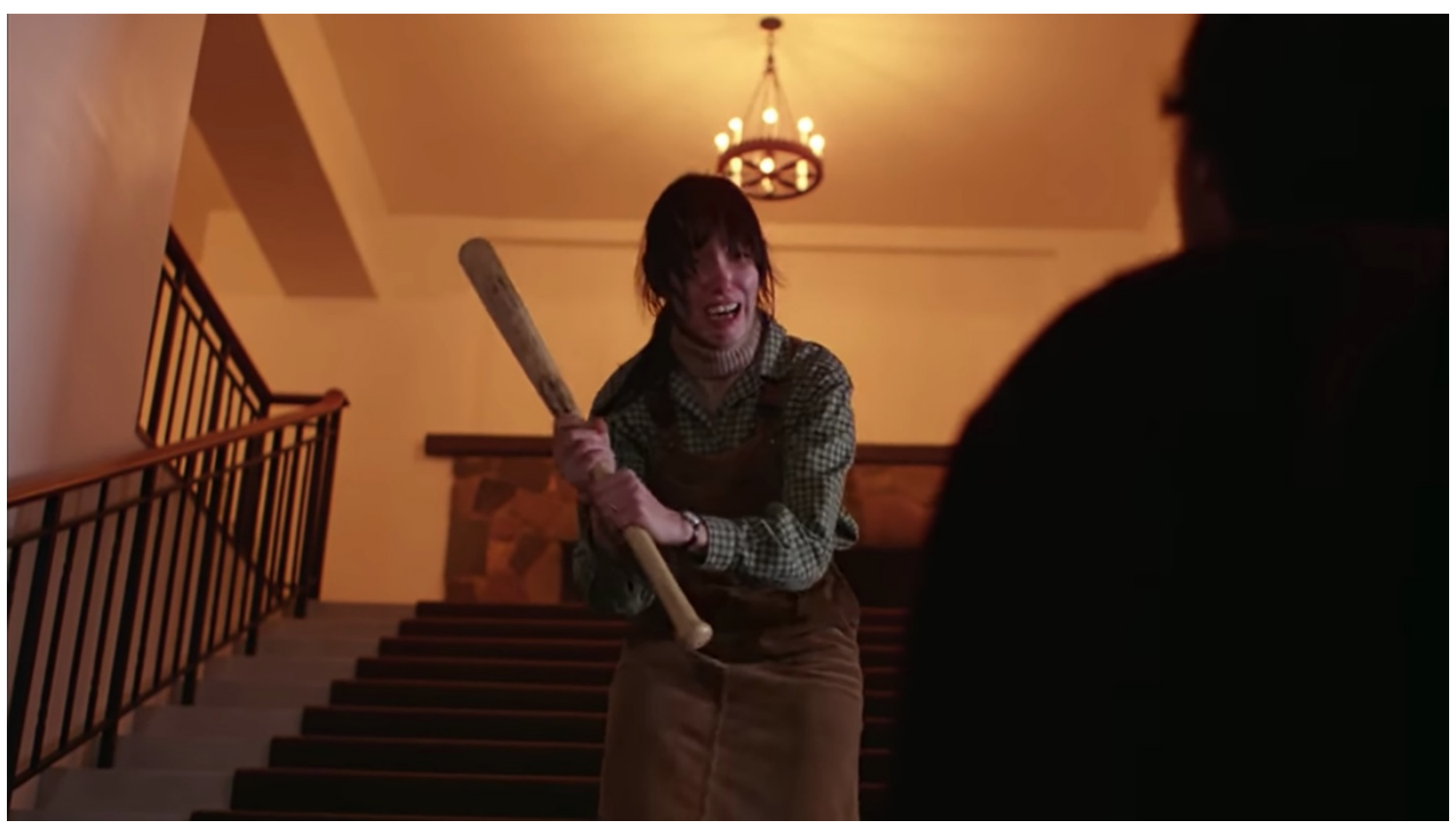

Şekil 17: Wendy ve Jack'in basamaklarda tartışması (Kubrick, 1980)

Sahnenin mekân seçiminin ne denli önemli olduğunun fark edilmesi için aynı sahnenin belirtilen bu özelliklere sahip olmayan, yani bir merdivende geçmeyen halinin düşünülmesi yeterlidir. Kubrick'in kullandığı bu mekân dışında hiçbir mekân sahnedeki gerilimin seyirciye yansıtılması için yeterli olmayacaktır. Merdivenin bu sahnede kullanımı yanı sıra yönetmenin yarattığı bir başka farklılık ise alışılagelmiş kovalamaca sahnelerinin aksine kaçan karakterin arka arka basamaklardan yukarı çıkması ve kovalayan karakterin yüzünün dönük ve yavaşça basamaklardan çıkmasıdır (Şekil 18). Bu karede kameradan daha alt kotta yer alan Jack'in karedeki konumu arkasında 
bulunan büyük lobi hacminin görüntülenmesine de olanak sağlar. Burada gerilim bir anda ortaya çıkarılmamış, bilinçli ve filmin özünde var olan tekinsizliği destekleyen bir şekilde yavaşça ve artan bir huzursuzlukla seyirciye yansıtılmıştır.

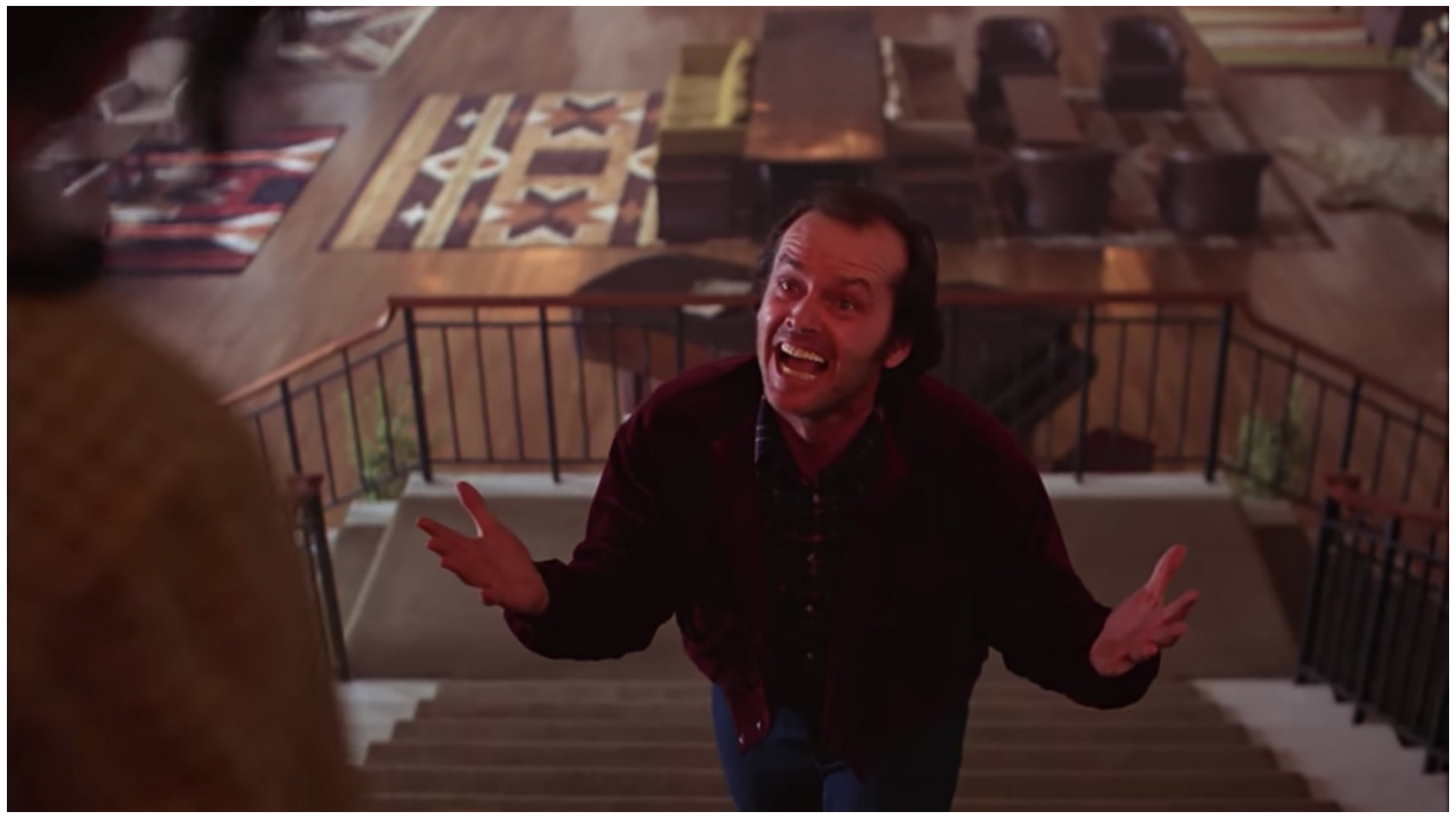

Şekil 18: Jack'in basamakları çıkışı (Kubrick, 1980)

Jack'in tırmanan gerilim ile birlikte basamakları yavaşça ve teker teker çıkmasının ardından, fiziksel olarak merdivenlerin en üst basamağına gelip, bir anda aşağı yuvarlanması da anlatımın mimari bir unsurla desteklenmesinin en net örneklerindendir (Şekil 19). Kubrick, dramatik aksiyonun tırmandığı bu sahnede, Jack ve Wendy arasındaki güç değişimini, Jack'in kontrolden çıkmasının sonucunda Wendy'nin gücü ele geçirmesini, merdiveni etkin biçimde kullanarak izleyiciye aktarmıştır (Walker, 1999).

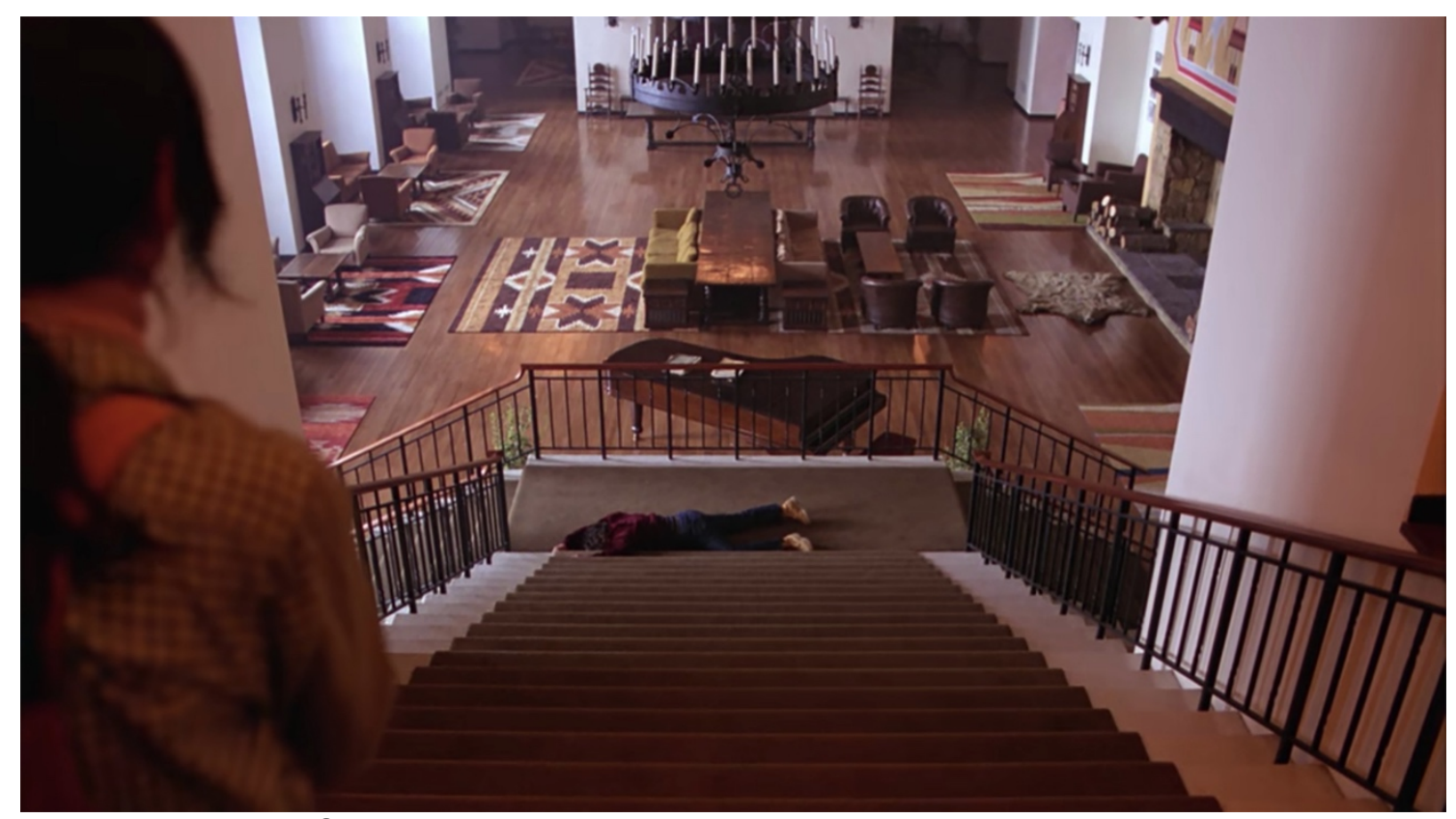

Şekil 19: Jack'in merdivenlerden düşüşü (Kubrick, 1980) 
Filmde merdivenin kullanıldığı diğer bir sahne ise Wendy'nin oğlu Danny'i Jack'ten korumak amaçlı otelin içinde telaşlı bir şekilde aradığı sahnedir (Şekil 20).

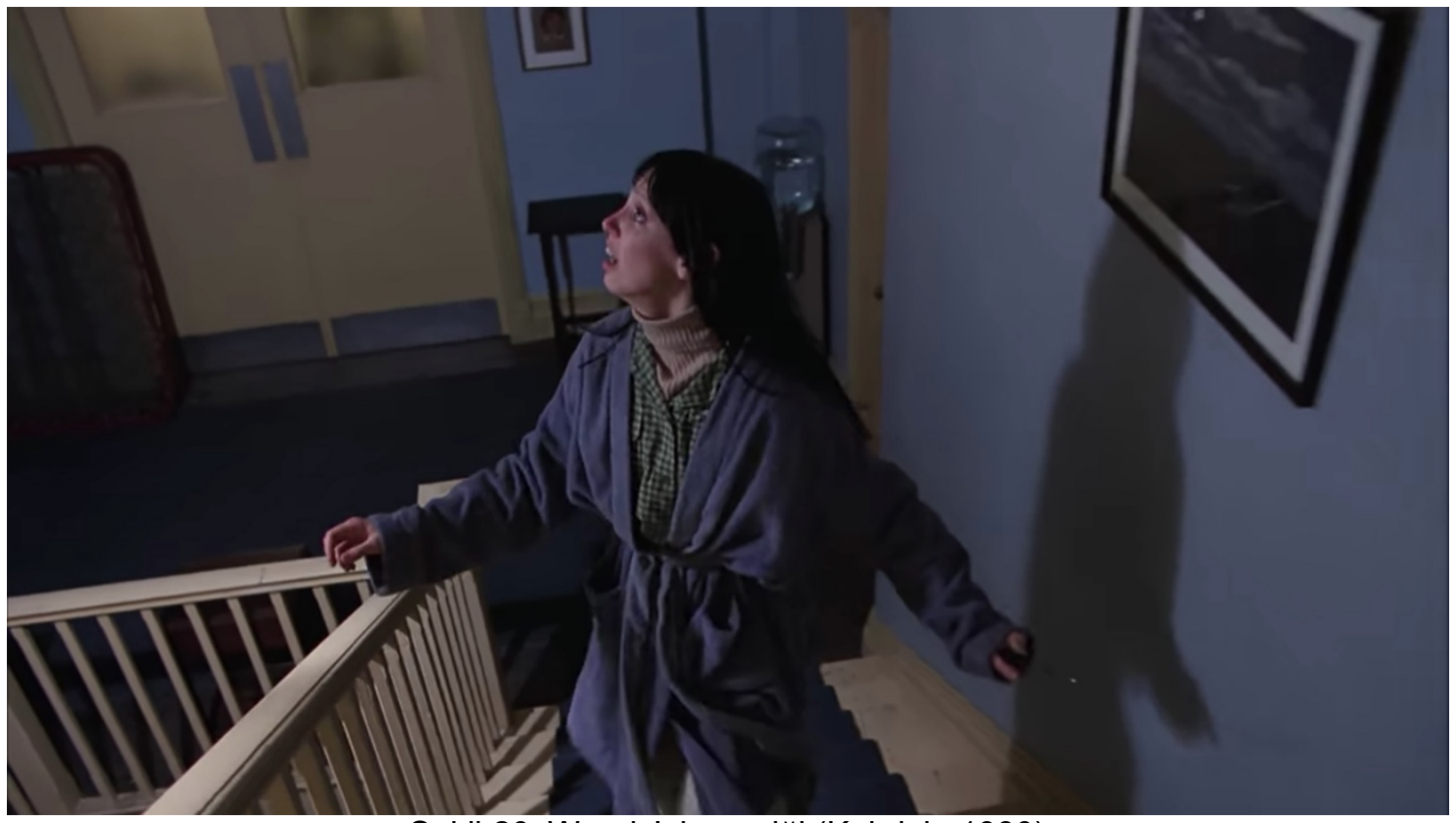

Şekil 20: Wendy'nin paniği (Kubrick, 1980)

Wendy'nin panik halinde oğlunu ararken merdivenleri acele ile çıkışı, Escher'in çizimlerindeki (Şekil 21) baş dönmesini andırır. Özellikle koridorlar ve merdivenler, Escher'in uzaysal ve paradoksal çizimleri gibi yönelim bozukluğu ve baş dönmesi ile karmaşık ve sonsuz bir labirent yaratır (Pallasmaa, 2007).

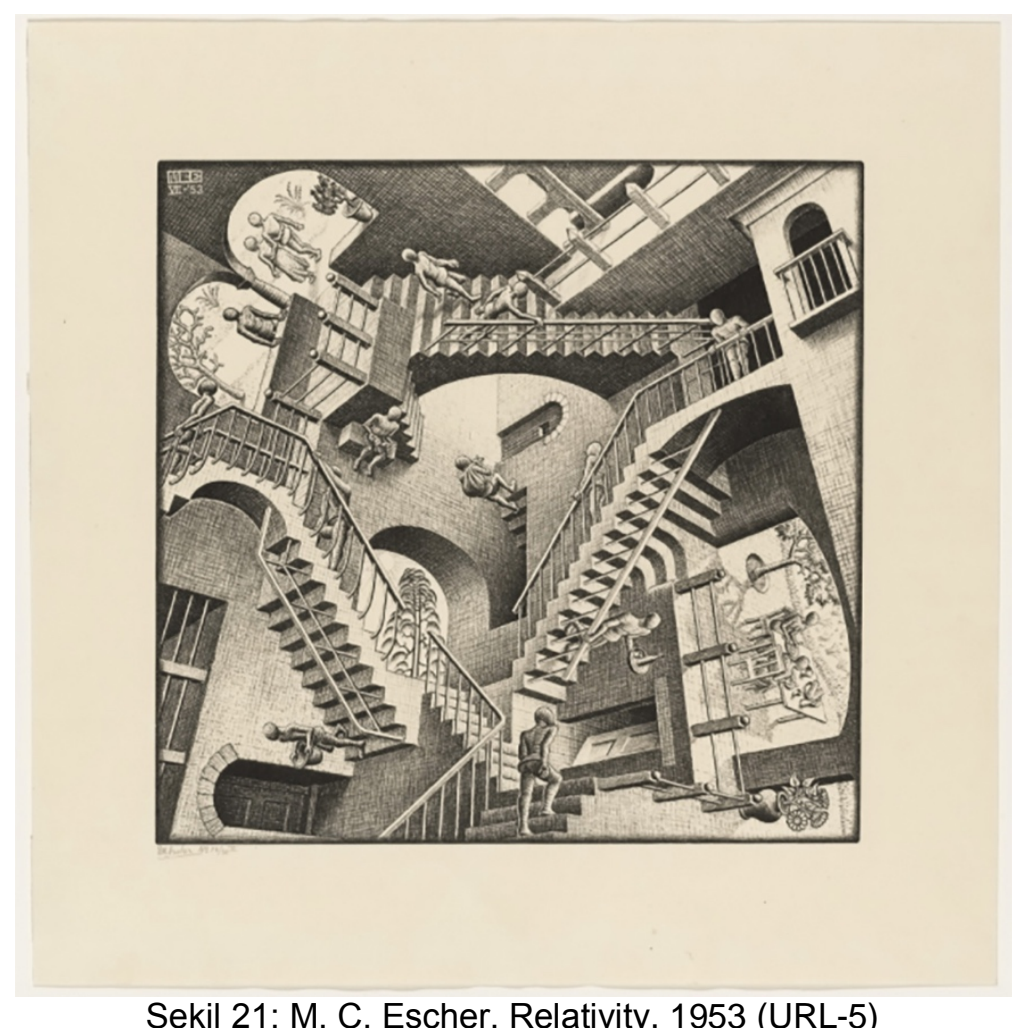

Şekil 21: M. C. Escher, Relativity, 1953 (URL-5) 
Overlook Oteli'nin mimari yapısı artık açık değildir. Görsel imaj, tekinsizliği desteklercesine ve rahatsız edici düzeyde kesin ve açık olmasına rağmen mekânsal algının muğlaklığı söz konusudur. Filmdeki çoğu mekânın konumu ve mekânlar arasındaki ilişki algılanamamaktadır.

\subsection{Balo salonu - yanılsama}

Sinemada kullanılan otel genel mekânlarının özellikle balo salonları ve lobilerin sahip olduğu gerilim potansiyeli birçok yönetmen tarafından filmlerde sıkça kullanılmıştır. Bu mekânlarda insanlar topluluk içinde yer edinebilmek için maskelerini takar ve tekinsiz bir kibarlıkla sohbet edip sosyal statülerini olabildikçe dışa vurmaya uğraşırlar. Bu tedirginlik ve gerilim içinde cinayetler işlenir, içkilere zehir konur, katiller pusuya yatar etrafı gözlemler ve kalabalığın içinde gizlenirler.

The Shining'de balo salonunda geçen sahneler 1920lerde düzenlenen bir baloya aittir. Goldroom, The Shining için kendini filmin geçtiği diğer tüm mekânlardan ve otelden izole etmiş bir balo salonudur. Jack ve seyirci Goldroom'a girdiklerinde adeta artık Overlook'ta değil, tamamen farklı bir şehirde farklı bir zaman ve otelde var olurlar.

Bu mekânda geçen sahneler Jack'in hayal dünyasının dışa vurulduğu sahnelerdir. Seyirci de Jack ile birlikte boş otelden çıkar ve insanlarla dolu, içkilerin yudumlandığı ve müzik eşliğinde sohbet edilen bir balo salonuna girer. Goldroom'a ulaşmak için geçilen koridor balo salonu ve burada geçecek olaylar hakkında seyirciye bilgi verir. Oteldeki hiçbir mekân Goldroom'a ulaşan koridor kadar parıltılı ve varlık göstergesi renkler ile tasarlanmamıştır (Şekil 22). Duvarlardan aydınlatma elemanlarına kadar 'lüks' seyircinin gözüne çarpar. Bu koridor oteldeki en prestijli mekâna giden koridor olmakla birlikte, otelde konaklayan insanların da kendi odalarından (mahremlerinden) çıkıp, en güzel giysilerini giyip, süslenip sosyalleşmek amacıyla toplandıkları mekândır.

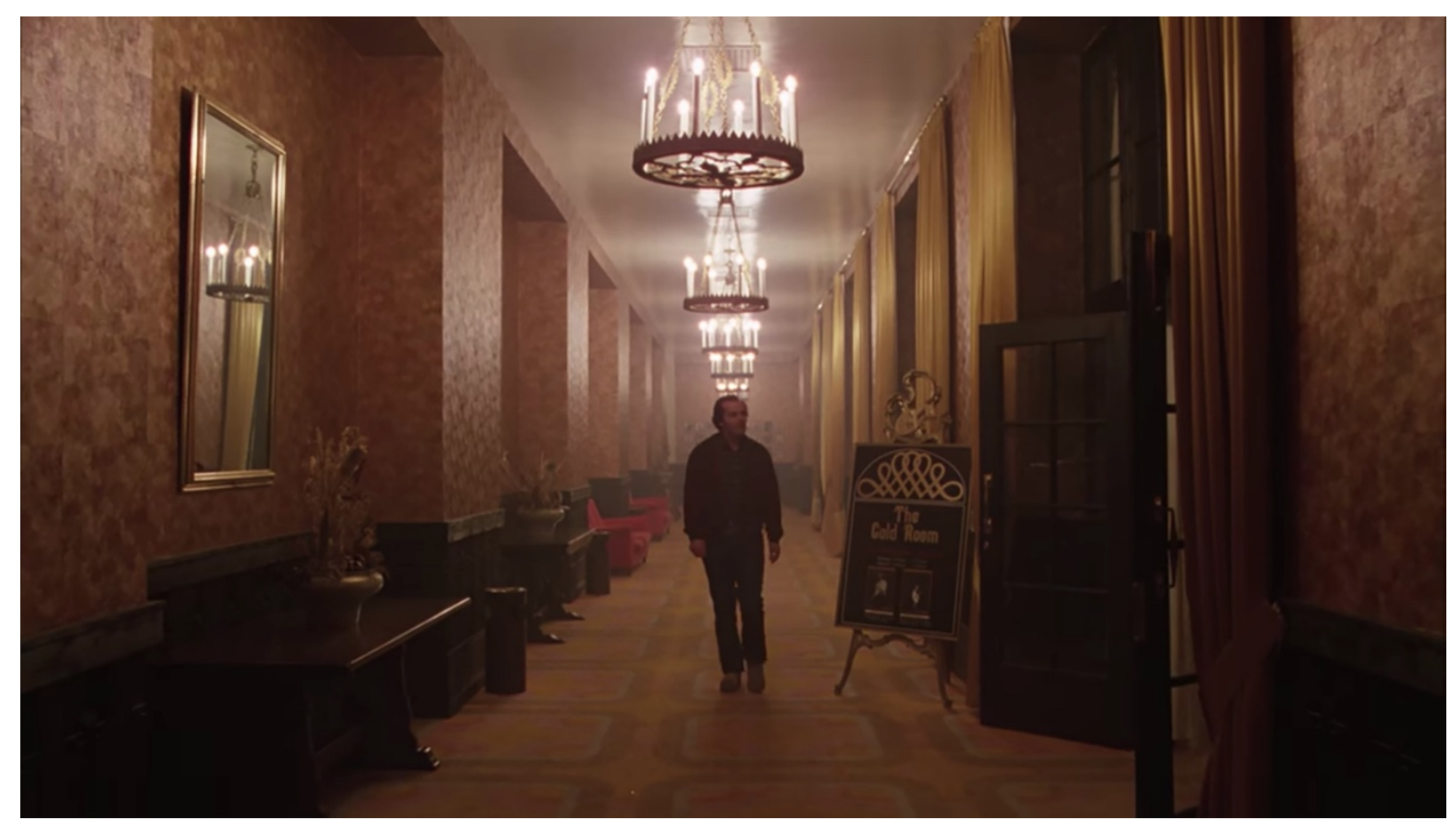

Şekil 22: Jack Goldroom'a gider (Kubrick, 1980) 
Goldroom öncelikle Jack'in tek başına salonu ziyareti ile seyirciye dönüş yapar. Jack'in cinnetini besleyen dev mekânlardan biri olan Goldroom'a gidişi otelden ve ailesinden biraz kopup eski alışkanlığı olan alkole tekrar kendisini bırakması ile başlar. Jack'in salona gidip barda oturduğu sahne görsel açıdan koridorlarda etkileyici biçimde seyirciye verilen perspektifin tekrar karşılaşıldığı sahnedir (Şekil 23).

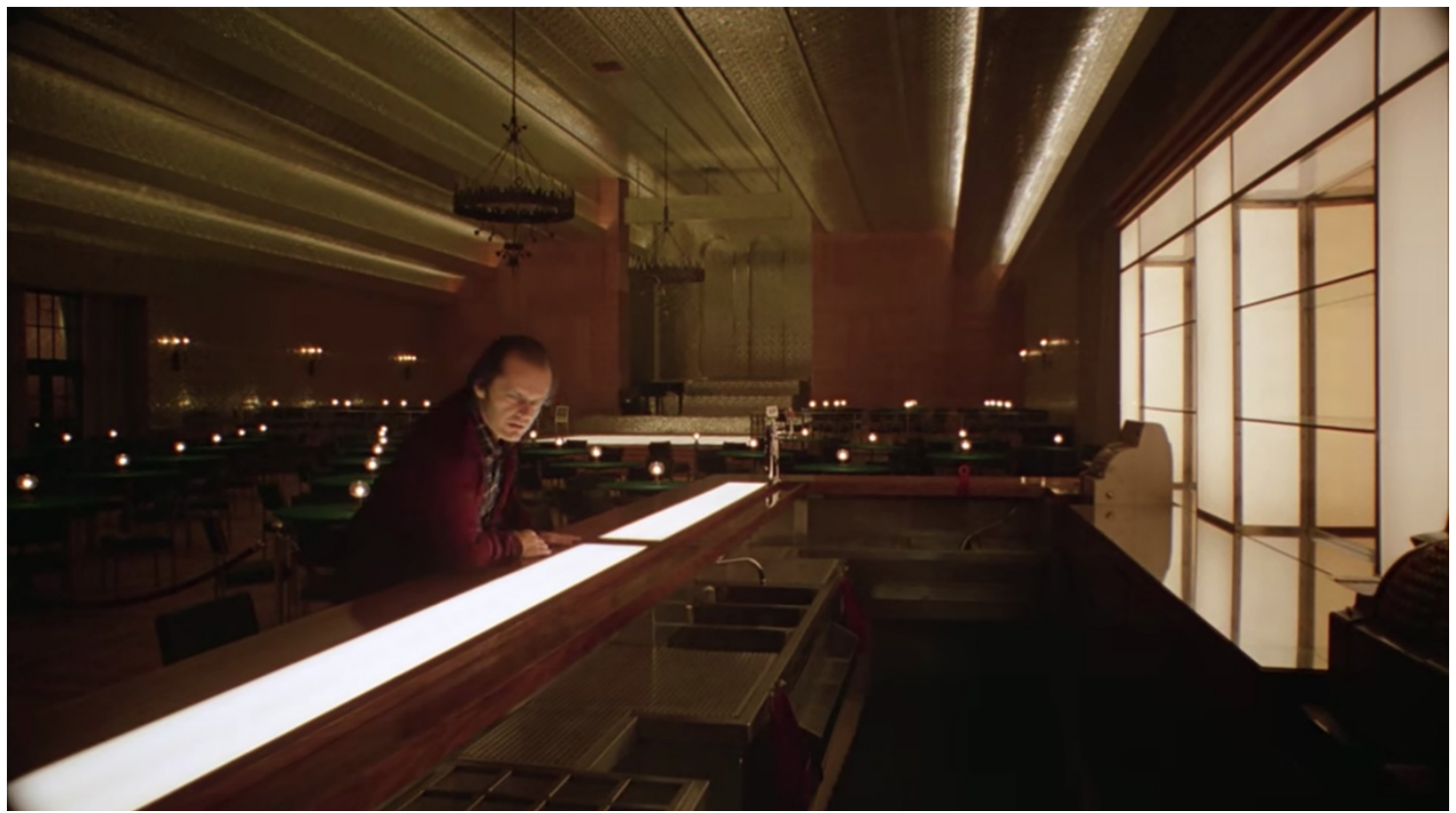

Şekil 23: Jack Goldroom'da (Kubrick, 1980)

Barın üzerinde ve tavanda devam eden çizgileri meydana getiren aydınlatma ve ışııtılı renkler mekânın tavan yüksekliğinin ve hacminin ne denli büyük olduğunun algılanmasındaki en önemli unsurlardır. Jack'in daha önce lobide görülen insan mekân ölçeğinin büyük farkı Goldroom'da da hissedilir. Çünkü bu mekânların normal kullanımında insan sayısının fazla olması gerekirken Jack bu sahnelerde tek başına var olur. Bu dev mekânların yarattığı boşluk ise Jack'i yutar niteliktedir.

Jack kendisini üzerinde hissettiği psikolojik baskının bir sonraki evresinde, cinnete biraz daha yaklaştığında, Goldroom'u artık büyük ve boş bir mekân olarak değil, içinde insanların dolu olduğu, kıyafet ve müzikten anlaşılacağı üzere 1920lerde geçen bir baloda bulur (Şekil 24). 


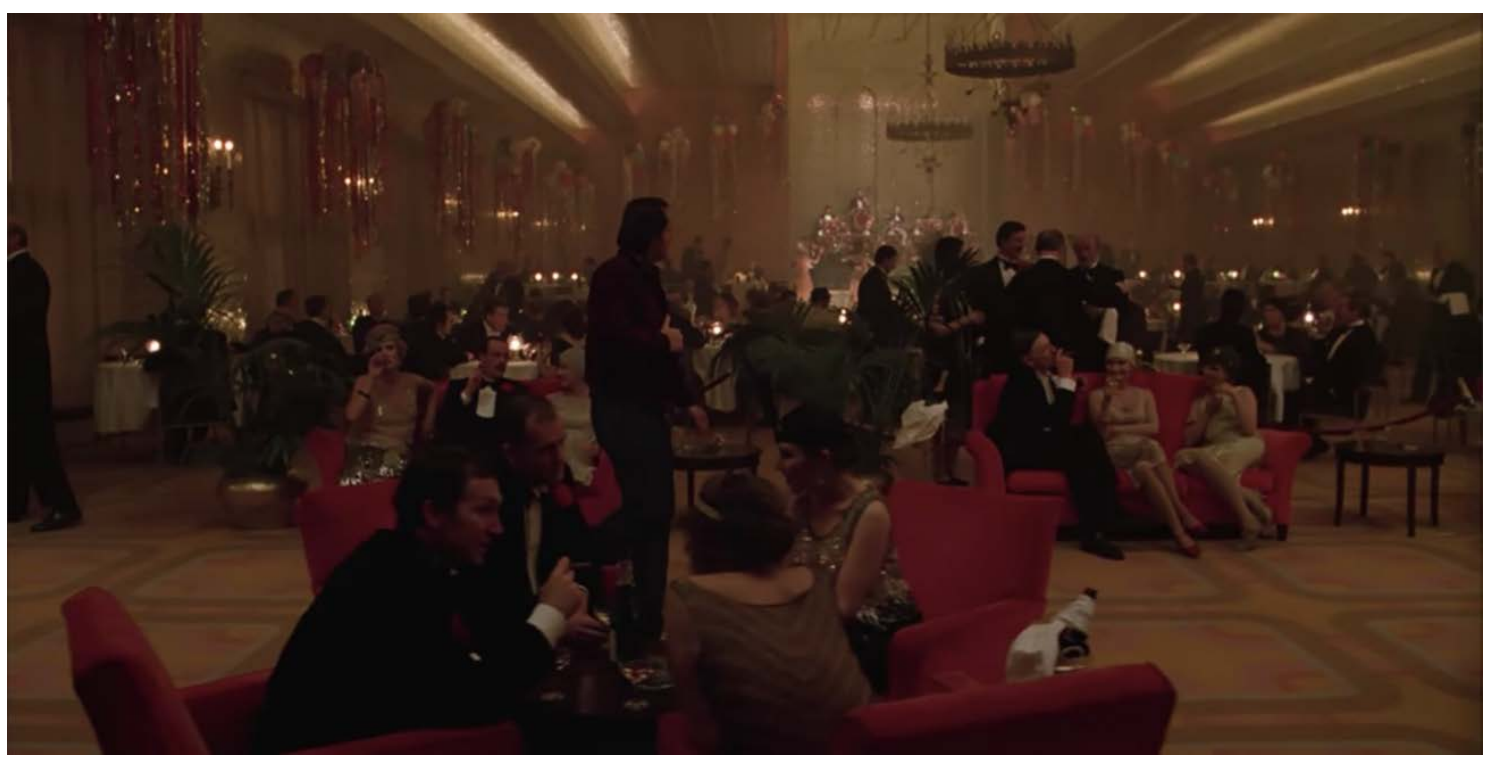

Şekil 24: Balo (Kubrick, 1980)

Mekân, seyircide Jack'in salona tek başına geldiği sahnedeki gibi bir etki yaratmaz çünkü içi olması gereken insan sayısı ile doludur. Jack burada yalnız değil bir topluluk içinde var olmuştur. Ailenin otelde yalnız oldukları bilindiğinden bahsedilen hayal dünyasının devreye girdiği anlaşılır. Goldroom artık sadece otelin herhangi bir mekânı değil, Jack'in cinnetinin ve hissettiği psikolojik baskının bir ürünü olan hayal dünyasıdır.

Filmin son sahnesi, yine Kubrick'in vazgeçemediği tekinsizlik metaforu olan simetri ile Goldroom'da son bulur. Sahne bu kez Goldroom'un içinden girişinin görüleceği açıdan çekilmiştir, görüntü tamamen simetriktir ve kameranın yavaşça yaklaştığı obje mekânın merkezinde yer alan fotoğraflardan oluşan panodur (Şekil 25). Simetriyi vurgulayan en önemli mekânsal unsurlar görüntünün çerçevelediği karede iki yanda yer alan kırmızı kolonlardır. Kırmızının filmdeki kullanımının bir örneği de yine bu kolonlardır.

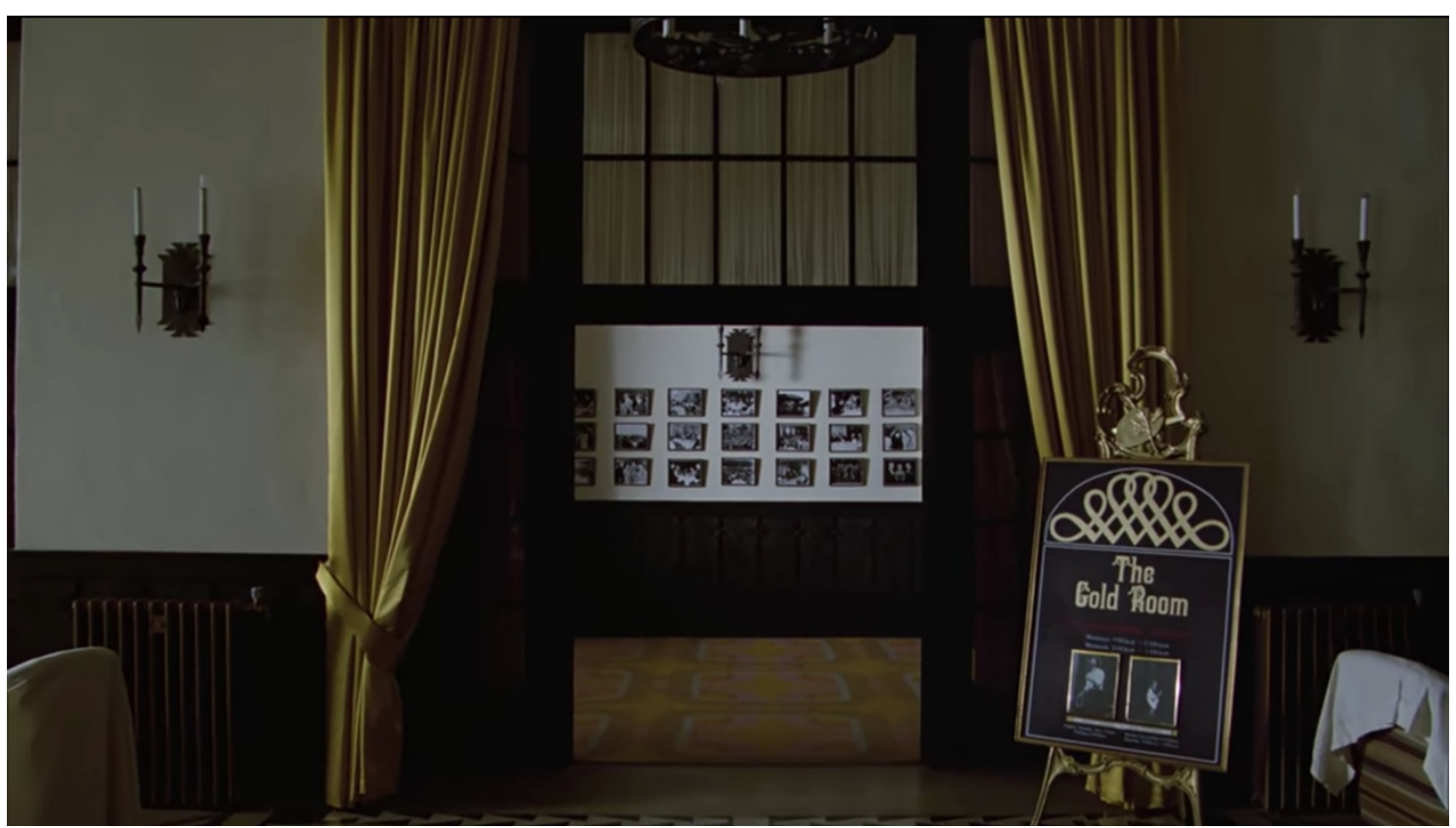

Şekil 25: Fotoğraflar (Kubrick, 1980) 
Simetri Kubrick'in öylesine etkili ve sık biçimde kullandığı bir unsurdur ki, filmin son sahnesi olan bu sahnede kameranın yavaşça yaklaştığı fotoğraf bile diğer fotoğrafların ortasına konumlandırılmış olan fotoğraftır. Hatta fotoğrafta yer alan 1920lerdeki Jack de insanların tam ortasında yer alır (Şekil 26). Filmin genel anlatımına hâkim olan simetri, filmin en sonuna kadar kararlı bir biçimde var olmuştur. Bu son kare ile film seyircinin düş gücüne açık bırakılarak son bulur.

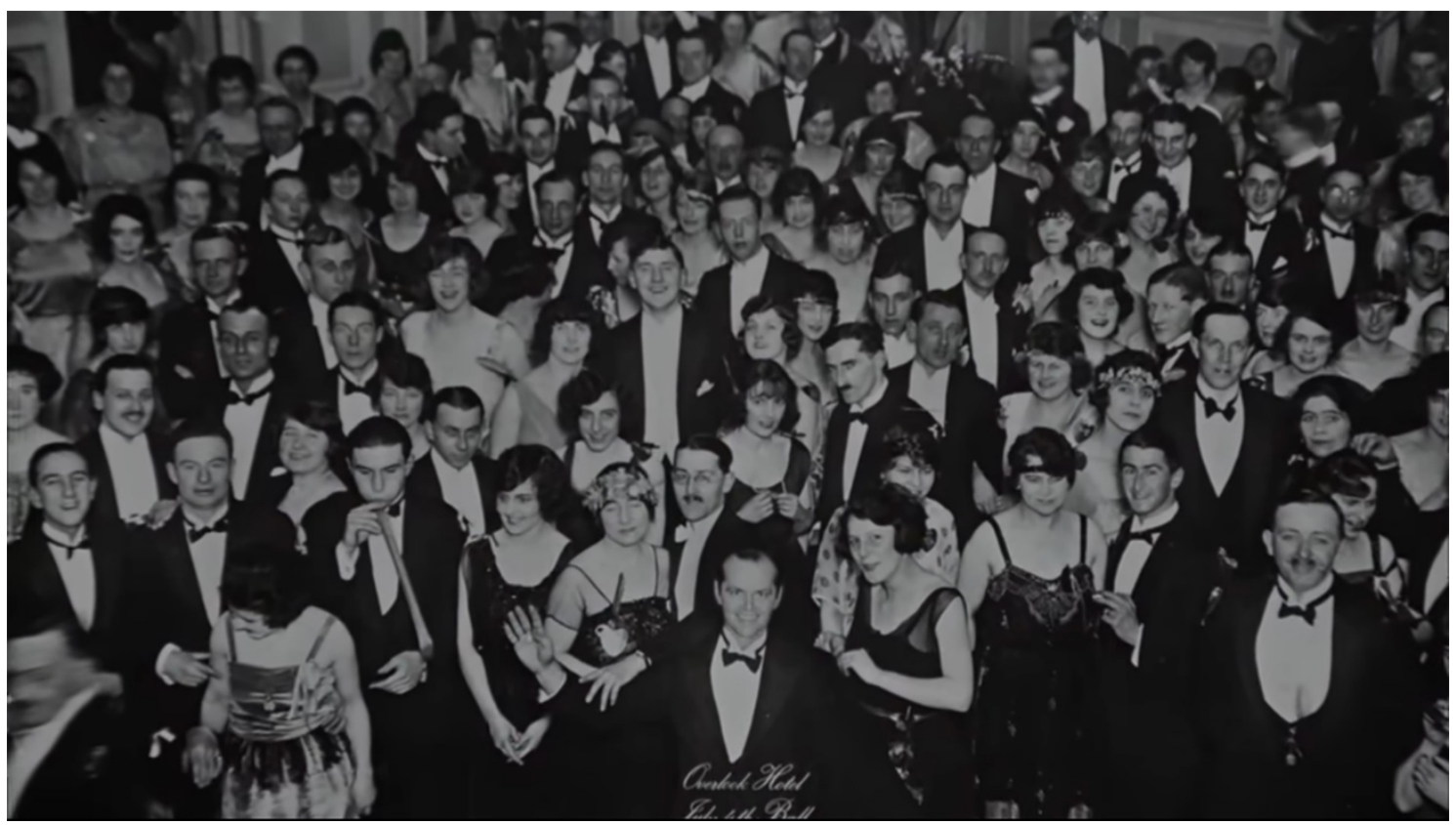

Şekil 26: Jack 1921'deki baloda (Kubrick, 1980)

\subsection{Banyo - saldırganlık}

Kubrick' in The Shining'de gerilim ve vahşetin anlatımını en çok desteklediği unsur renktir. Bu renk tüm filmde sahnelerde kilit noktalarda kullandığı kırmızı renktir. Bu kullanım, filmin ilk yarısında mekân dışında filme yayılmış detaylarda gizlidir. Bu detaylar incelendiğinde Wendy'nin kırmızı botları, Danny'nin kırmızı kazağı, Wendy'nin kırmızı yağmurluğu ve oda 237'nin kırmızı anahtarlığı örneklerden bazıları olarak gösterilebilir.

Kırmızının bu kullanımlarının hiçbiri tesadüfi değildir, yönetmen bunlar ile seyirciyi bir vahşete hazırlamaktadır. Nihayet filmin kilit sahnelerinden birinde, Jack ve Grady'nin aile katliamını konuştuğu sahnede, mekâna yansımış ve kırmızı kullanımı zirveye çıkarak gerilim ve vahşet doruk noktasına ulaşmıştır. Bu mekân vahşetin aleni olarak ilk defa dile getirildiği kırmızının baskın olduğu Goldroom'un tuvaletidir (Şekil 27). 


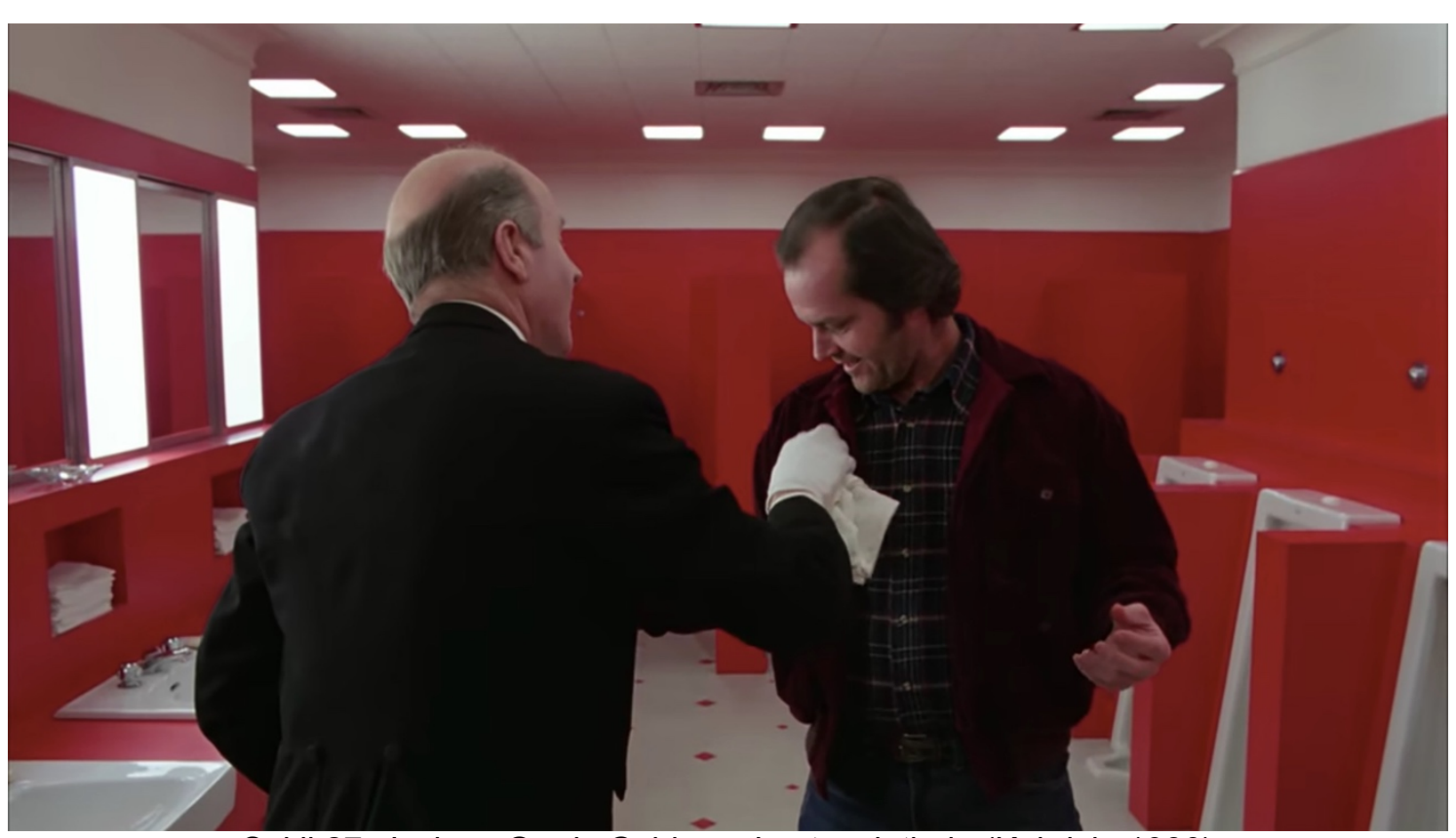

Şekil 27: Jack ve Grady Goldroom'un tuvaletinde (Kubrick, 1980)

Filmde yer alan diğer bir banyo sahnesi ise yine Jack'in hayal dünyasında yarattığı sahnelerden biridir. Girilmesi yasak olan oda 237'ye giren Jack, odanın banyosunda bir kadın ile karşılaşır. Bu kadın Jack'in hoşuna gidebilecek güzelliğe sahip olan küvette yatan bir kadındır. Banyoya hâkim olan yeşil renk, yine rengin baskın olarak kullanıldığı diğer bir banyodur (Şekil 28). Filmde bu banyoların ortak yanı ikisinin de bir renk ile algıda yer almasıdır. Diğer mekânlar seyircide ölçek, aydınlatma gibi diğer unsurlar ile bilinçte yer edinirken bu iki banyo sahnesi rengin baskınlığı ile var olurlar. Banyo yine tüm filme hâkim olan simetri ile görüntüde yerini alır. Daha önce bahsedilen ayna kullanımı ise yine burada tekrarlanmış ve gerçeği gösteren öğe olarak kullanılmıştır. Kadına sarılan Jack, aynadaki yansımalarına bakarak kadının aslında hayalindeki gibi güzel olmadığı aksine çürümüş, şişmiş ve morarmış yaşlı bir kadın bedeni olduğunu görür. Sahnenin içeriği, mekândaki renk seçimi ile örtüşür - çürüyen bir bedene ev sahipliği yapan yeşil bir banyo. 


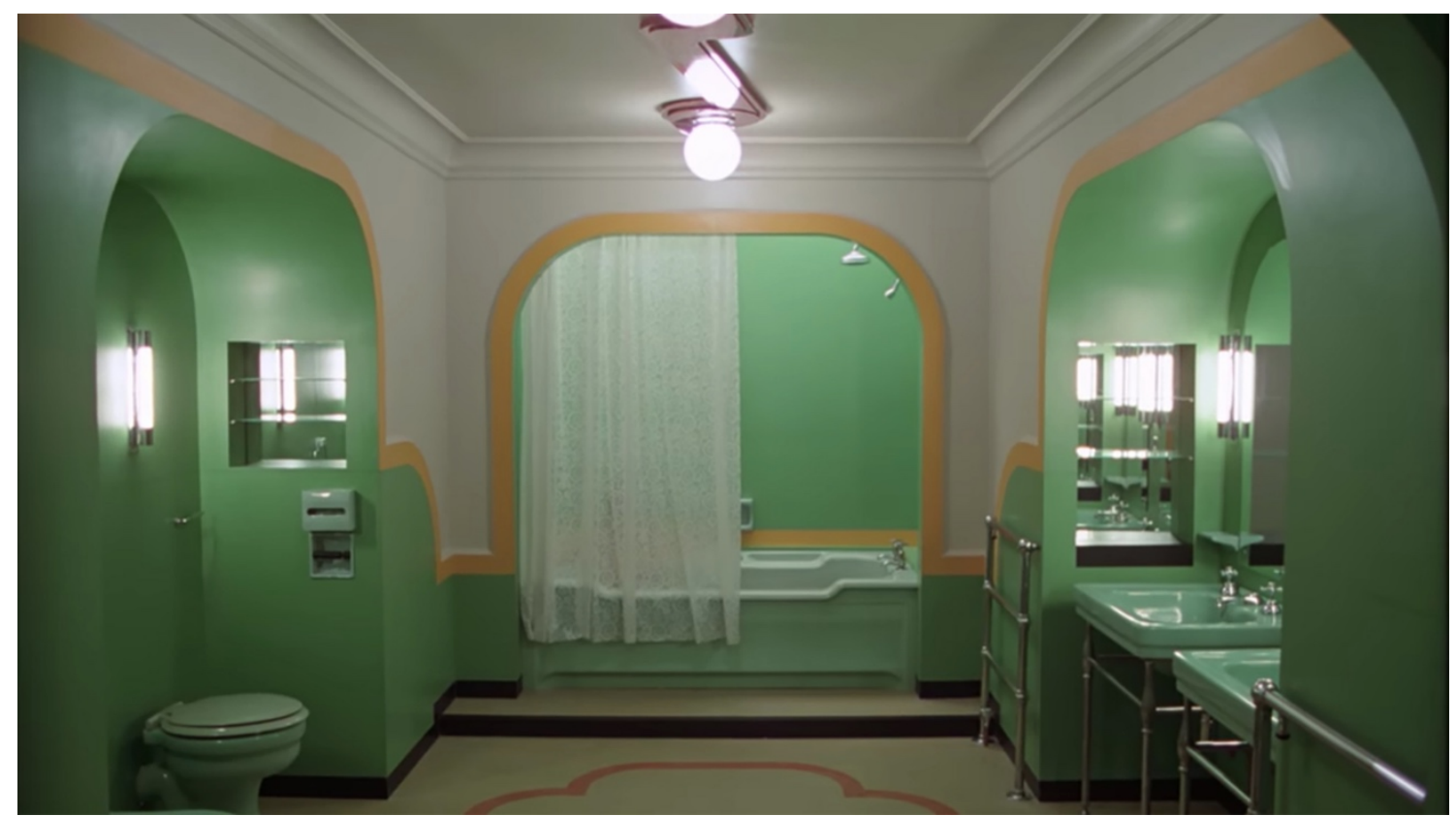

Şekil 28: Oda 237 banyosu (Kubrick, 1980)

Torrence Ailesinin odası bölümünde incelenmiş olan odanın banyosu ile birlikte bu iki banyo incelendiğinde Kubrick'in filmde banyo kullanımına verdiği önem ve mekânın dramatik aksiyon için ne denli etken bir rol oynadığı açıkça görülmektedir. Artık mekân, film için sadece pasif bir dekor değil, baş rol oyuncularından biri haline gelmiştir.

\section{DEĞERLENDIRME VE SONUÇ}

Bu çalışmada sinema mimarlık ilişkisi, mekân olgusu ve mekân duyumsamaları açısından fenomenolojik yaklaşımla incelenen film Stanley Kubrick sinemasından 'The Shining' filmidir. The Shining, Colorado dağlarındaki Overlook Oteli'nde kış bekçisi olarak çalışacak olan Jack ve ailesinin yaşadıklarını konu almaktadır. Otel kışın kapalı olduğundan Jack ve ailesi uzun bir süre boyunca mekânda yalnız kalacaklardır. Film bu kış mevsimi süresince Jack'in psikolojik çöküşü ve cinnete sürüklenişini anlatmaktadır.

The Shining filminin mekânı olan Overlook Oteli'nin karakterler ve izleyicide yarattığı temel duyumsama 'tekinsizlik'dir. Filmde, otelde sadece üç kişi oldukları bilinen fakat her koridor dönüşünde tedirginlik ve gerilim yaratan işte bu 'tekinsizlik' olgusudur. Overlook Oteli'ne ve filme hâkim olan duyumsama, psikanalizde kaygının kaynağı olarak bilinen 'tekinsizlik'tir ve bu duyumsama otelin mekânları üzerinden seyirciye aktarılmıştır.

Filmin ana mekânları olarak belirlenen lobi, koridor, ailenin odası, asansör, labirent, merdiven, balo salonu, banyo ve bu mekânların yansıttıkları duyumsamalar eşleştirilerek değerlendirilmiş ve aşağıdaki sonuçlara ulaşılmıştır.

Filmdeki lobi sıkışmışlık duygusunu yansıtmaktadır. Otellerin hacim olarak en büyük bölümlerinden biri ortak kullanım alanı olan lobinin, filmde insan - mekân ölçeğinin en iyi okunabildiği hacim olduğu, bu ölçek farkının insanın bu hacim içinde kendini ne denli yalnız ve sıkışmış hissettiği belirlenmiştir. Lobinin yarattığı duyumsamanın bu psikolojik çöküş evresinin anlatımındaki etkisi açıkça görülmektedir. 
Filmde otelin koridorları tedirginlik duygusunun öne çıktığı hacimler olarak belirlenmiştir. Yapılarda ana mekânlar arası bağlantıyı sağlayan koridorlar her zaman mekânla açık bir ilişki oluşturmazlar, bu nedenle kontrol altına alınamayan biçimlerde, yönelim bozukluğu yaratabilen aldatıcı hacimler yani labirentler yaratabilmektedir. Filmdeki koridor, otelin mimari gereksinimleri için bir ara mekân olmaktan çıkarılarak otelin dev bir labirente dönüşmesi için kullanılmış ve bu labirent içinde gezen izleyicinin köşe dönüşleri ile tedirginleşmesi sağlanmıştır.

Torrence Ailesi'nin Odası filmde tekinsizliği en çok yansıtan mekânlardan biridir; bu tekinsiz olma durumu mekâna hâkim olan güvensizlik duygusu ile seyirciye aktarılmıştır. Ailenin kendi dünyalarına çekildikleri, mahremiyetlerinin sembolü olan otelde konaklayacakları süre boyunca onların 'ev'i görevini üstlenecek olan mekân, otel odası tekinsizlik olgusunun özü olan 'ev' kavramının işlendiği mekândır. Bu mekânda kullanılan aynanın hem karakter hem de mekân bağlamında kötücül ikiz oluşturduğu, bu ikizlik olgusunun ise tekinsizliği destekleyen en büyük unsur olduğu saptanmıştır.

Otelin asansörü Kubrick'in metaforik anlamlar yüklediği hacim olarak kullanılmıştır. Asansör, tekrar edilen sahnelerle seyircide belirsizliğin yarattığı korku duygusunu uyandırmaktadır. Asansör, çağdaş mimaride yapılan teknik tanıma göre yapılardaki dikey sirkülasyonu sağlayan salt işlevsel bir öğe olarak değil insan beyninde yarattığı imgelem olarak var olur. Bu belirsizliğin ve korkunun filmde kurgudan bağımsız olarak tekrarlanan asansörden kan boşlama sahnesi ile seyirciye yansıtılması, gerilimi tırmandıran bir diğer olgu olarak belirlenmiştir.

Labirent filmde kaybolmuşluk hissinin seyirciye aktarıldığı mekân olmuştur. Mitolojik anlamı ve tarif edilmeyi imkânsız kılan, sürekli kararsızlık ve rahatsızlık yaratan yanı ile labirent, Kubrick'in filmde tüm bu anlam derinlikleri ile kullandığı bir mekândır. Labirent, içinde bulunulduğunda duvarları yüksek, koridorları sağa sola keskin biçimde kıvrılan, mekânsal hiçbir yönlendirme yapmayan, içinden çıkılamaması için tasarlanmış, gerilimin, paniğin ve kaybolmuşluğun adeta mekânlaştırılmış halidir. Labirentin film için hem fiziksel hem de metaforik açıdan büyük önem taşıdığı saptanmıştır.

Otelin merdivenleri hem fiziksel yapısı ile hem de dramatik aksiyonu güçlendirici özelliği ile tırmanan korku ve panik duygusunun seyirciye aktarıldığı hacimlerdir. Mimari yapılarda dikey sirkülasyonun sağlandığı birimlerden biri olan merdiven, doğasında var olan dikey formu, tırmanma, yükselme, artma gibi olguları içinde barındırmasından dolayı filmde doruk anların yaşandığı mekânlar olarak kullanılmıştır. Merdivenin filmde dramatik aksiyonu desteklemek ve güçlendirmek amaçlı kullanıldığı, yaratmak istediği duyumsama olan korku ve paniğin öyküsel anlatı ile de desteklenerek izleyiciye yansıtıldığı görülmüştür.

Otelin Goldroom isimli balo salonunda geçmiş senelere ait sahnelerle Jack ve seyirci için bir yanılsama duygusu yaratılmıştır. Filmde Jack'in gördüğü sanrıların anlatıldığı mekân olan balo salonu, otelin en büyük genel mekânlarından biridir. Jack'in hayal dünyasının dışa vurulduğu sahnelerin mekânı olan balo salonu, müzik eşliğinde sohbet eden birçok insanın sosyal statü gösterişi ile çevrelerini yanılttıkları ve adete görünmez maskelerle bulundukları bir mekândır. Jack'in yanılsamalarının bu mekânda izleyiciye aktarılmasının nedeninin bu anlamda metaforik bir gönderme ile yapıldığı düşünülmektedir.

Otelin oda banyoları ve genel mekân tuvaletleri vahşetin zirve noktaları olan sahneler için kullanılan mekânlar olmuştur; saldırganlık bu mekânlar ile eşleşen duyumsamadır. 
Filmde renk unsurunun en etkin biçimde kullanıldığı banyolar, kırmızı ve yeşil rengin mekânsal anlatımla izleyicide farklı duyumsamalar yaratması amacıyla kullanılmıştır. Kırmızının izleyiciyi vahşete hazırladığı ve bu rengin itkisel gücü ve sembolik anlamları ile alt bilinçte gerilim yarattığı gözlemlenmiştir. Yeşil rengin baskın olduğu diğer banyoda ise çürümüş bir kadın bedeni ile karşılaşılması, rengin etkin olarak kullanıldığı sahnelere bir örnek oluşturmuştur. Bu bağlamda anlatının renk ile güçlendirildiği sahnelerde rengin mekân üzerinden verilmesi, mekânın bu anlatı için birincil etken olduğunu göstermektedir.

Bu çalışmada, mekânsal duyumsamanın mimarlıkta hem kuram hem de uygulama için önemli bir unsur olduğu, mekânın ve mimarlığın insandan bağımsız düşünülemeyeceği, zaman ve mekân kavramları ile var olan sinema aracılığıyla vurgulanabileceği, mimarlığın mekânsal duyumsama bağlamında kendine sinema aracılığıyla çıkarımlar yapabileceği ve bu çıkarımlar içinde disiplinlerarası yaklaşımla sinema ve mimarlık ilişkisinin üzerinde durulması gerektiği sonucuna varılmıştır. Pallasmaa'nın (2007) sinema ve mimarlık etkileşimi ve son yıllarda bu konuda yapılan çalışmalar ile ilgili verdiği örnekler bu etkileşimin yadsınamaz ölçüde önemli olduğunu kanıtlar niteliktedir.

\section{KAYNAKLAR}

Freud, Sigmund, The Uncanny, Çev.: David McLintock, Penguin Books, London 2003.

Kluge, Friedrich, "Etymologisches Wörterbuch der deutschen Sprache", Unter Mitarb. von Max Bürgisser u. Bernd Gregor, völlig neu bearbeitet von Elmar Seebold. 22. Auflage, , de Gruyter, Berlin, New York 1989, s. 301.

Köseoğlu, Emine, Tasarım Girdisi Olarak Algılama: Lobi Mekânının Algılanmasında Kullanıcı Kültürünün Etkisi, Yüksek Lisans Tezi, Yıldız Teknik Üniversitesi, FBE, İstanbul 2004.

Merleau-Ponty, Maurice, Göz ve Tin, 3. B., Çev.: Ahmet Soysal, Metis Yayınları, İstanbul 2006.

Nelson, Thomas Allen, Kubrick, Inside a Film Artist's Maze, Indiana University Press, Bloomington 2000.

Pallasmaa, Juhani, The Architecture of Image, Existential Space in Cinema, Rakennustieto Publishing, Helsinki 2007.

Pekol, Banu, Tasarımda Labirentler, Radikal Gazetesi Tasarım Eki, İstanbul, Ağustos 2010.

Usai, Paolo Cherchi, "Kubrick as Architect", Cinemas: Journal of Film Studies 9(1), 1998, ss. 117-136.

Walker, Alexander, Stanley Kubrick, Director, W. W. Norton \& Company, New York 1999.

Warner Brothers \& Kubrick, Stanley (Producers), Stanley Kubrick (Director), The Shining [Motion Picture], Warner Bros, USA 1980. 
Žižek, Slavoj, Mimari Paralaks. Sınıf Savaşının Spandrelleri ve Diğer Fenomeni, Çev.: Bahadır Turan, Encore Yayınları, İstanbul 2011.

URL-1: Jameson, Richard T., Kubrick' Shining. Film Comment, 1980. https://www.filmcomment.com/article/stanley-kubrick-the-shining/ (Son Erişim Tarihi: 23.04.2020, 23.30)

URL-2: https://www.artic.edu/artworks/67958/identical-twins-roselle-n-j (Son Erişim Tarihi: 24.04.2020, 00.06)

URL-3: http://mmmgroup2.altervista.org/e-labiri.html (Son Erişim Tarihi: 23.04.2020, 22.00)

URL-4: https://www.moma.org/collection/works/60110 (Son Erişim Tarihi: 24.04.2020, 00.11)

URL-5: https://www.moma.org/collection/works/61398 (Son Erişim Tarihi: 24.04.2020, 00.12) 